Research paper

\title{
Synthesis, characterization and anticancer activity of new 2-acetyl-5-methyl thiophene and cinnamaldehyde thiosemicarbazones and their palladium(II) complexes
}

\author{
Eunice A. Nyawade ${ }^{\mathrm{a}, \mathrm{b}, *}$, Nicole R.S. Sibuyi ${ }^{\mathrm{c}}$, Mervin Meyer $^{\mathrm{c}}$, Roger Lalancette ${ }^{\mathrm{d}}$, Martin O. Onani ${ }^{\mathrm{a}, *}$ \\ ${ }^{a}$ Organometallics and Nanomaterials, Department of Chemistry, University of the Western Cape, Private Bag X17, Bellville 7535, South Africa \\ ${ }^{\mathrm{b}}$ School of Physical Sciences, Jomo Kenyatta University of Agriculture and Technology, P.O. Box 62, 000-00200 Nairobi, Kenya \\ ${ }^{\mathrm{c}}$ Department of Science and Innovation/Mintek Nanotechnology Innovation Centre (DSI/Mintek NIC), Biolabels Node, Department of Biotechnology, University of the \\ Western Cape, Private Bag X17, Bellville 7535, South Africa \\ ${ }^{\mathrm{d}}$ Department of Chemistry, Rutgers, The State University of New Jersey, Newark, NJ 07102, United States
}

\section{A R T I C L E I N F O}

\section{Keywords:}

Thiosemicarbazone

Thiosemicarbazide

Palladium(II) complexes

Cinnamaldehyde

Cytotoxicity

Anticancer activity

\begin{abstract}
A B S T R A C T
New thiosemicarbazone (TSC) ligands, AMT-C $=\mathrm{N}-\mathrm{TSCH}(\mathbf{L} 1), \mathrm{AMT}-\mathrm{C}=\mathrm{N}-\mathrm{TSC}\left(\mathrm{CH}_{3}\right)(\mathbf{L 2}), \mathrm{CIN}-\mathrm{C}=\mathrm{N}-\mathrm{TSCH}(\mathrm{L} 3)$ and $\mathrm{CIN}-\mathrm{C}=\mathrm{N}-\mathrm{TSC}\left(\mathrm{CH}_{3}\right)(\mathrm{L} 4)\left(\mathrm{AMT}=2\right.$-acetyl-5-methylthiophene, $\mathrm{TSCH}=$ thiosemicarbazide, $\mathrm{TSC}\left(\mathrm{CH}_{3}\right)=4$ methyl-3-thiosemicarbazide, CIN = cinnamaldehyde) were synthesized by condensation reaction. The reaction of $\left[\mathrm{PdCODCl}_{2}\right]$ with the ligands $\mathbf{L 1}, \mathbf{L 2}$ and $\mathbf{L} 4$ in the ratio $1: 1$ yielded complexes $[\mathrm{Pd}(\mathrm{L} 1) \mathrm{Cl}](\mathrm{C} 1),\left[\mathrm{Pd}(\mathrm{L} 2) \mathrm{Cl}{ }_{2}\right]$ (C2), and $\left[\mathrm{Pd}(\mathrm{L} 4)_{2} \mathrm{Cl}_{2}\right]$ (C4) respectively (COD = 1,5-cyclooctadiene). The reaction of $\left[\mathrm{Pd}(\mathrm{COD}) \mathrm{Cl}_{2}\right]$ with $\mathrm{CIN}$ $\mathrm{C}=\mathrm{N}-\mathrm{TSCH}(\mathrm{L3})$ in 1:2 metal to ligand ratio yielded the complex $\left[\mathrm{Pd}(\mathrm{L} 3)_{2}\right](\mathrm{C} 3)$. The ligands and the complexes were characterized by UV-Vis, FT-IR, NMR, elemental analysis and conductivity measurements. The ligand L1 coordinated to the metal in a tridentate fashion while L2, L3 and L4 coordinated in a bidentate fashion. The ligands $\mathbf{L 1}$ and $\mathbf{L 3}$ coordinated to the metal as thiol anions while ligand L4 coordinated via the thione sulphur. Conductivity measurements of the metal complexes in dimethyl sulfoxide showed that the chloride ions complexes C1, C2 and C4 are within the coordination spheres. The crystal structures of ligands L2 and L4 were obtained from a Bruker Smart KAPPA APEXII DUO diffractometer with graphite monochromated Mo Karadiation ( $\mathrm{k}=0.71073 \AA$ ). Cytotoxic activity of the compounds was investigated against the human cancer cell lines; Caco-2 (colon), HeLa (cervical), Hep-G2 (hepatocellular), MCF-7 (breast), PC-3 (prostate) and MCF12A (non-cancer breast) cells. The complex $\mathbf{C 2}$ exhibited excellent broad spectrum growth inhibition activity against all the human cell lines tested except for the non-cancer breast cells. All the metal complexes synthesized inhibited the proliferation of human prostate cancer cell.
\end{abstract}

\section{Introduction}

The chemistry of transition metal complexes of thiosemicarbazone (TSC) ligands has attracted a lot of research interests due to the numerous pharmacological properties portrayed by both the ligands and the complexes [1]. The excellent chelating property of TSCs has been an attractive feature in coordination chemistry hence the vast interest in their chemistry for a span of six decades [2-4]. The TSCs are a class of $\mathrm{N}, \mathrm{S}$ bidentate Schiff base ligands which are generally synthesized by the condensation of a ketone or an aldehyde with a thiosemicarbazide under suitable reaction conditions.

Since TSCs can exist as thione-thiol tautomers, they can coordinate to the metal center either in the neutral form or, an anionic form generated after loss of a proton from the thioamide nitrogen (NH) or thiol sulphur (SH). The TSC ligand coordinate to various metals in a bidentate manner via the $\mathrm{N}$ and $\mathrm{S}$ atoms or in a tridentate fashion if there is an extra donor group (D) such as $\mathrm{O}, \mathrm{N}$ or $\mathrm{S}$ in the molecule to give metal complexes of different geometries $[5,6]$. Various coordination modes exhibited by the TSC ligands have been documented [7]. Pd (II) and Pt(II) complexes with TSCs derived from 2-thiophenecarboxaldehyde, 5-methyl-2-thiophene carboxaldehyde and other aldehydes and ketones exhibit various coordination modes and have been reported to be biologically active [8-12]. The presence of nitrogen and sulfur donor atoms in the ligand may be responsible for their potential

\footnotetext{
* Corresponding authors at: Organometallics and Nanomaterials, Department of Chemistry, University of the Western Cape, Private Bag X17, Bellville 7535, South Africa.

E-mail addresses: enyawade@jkuat.ac.ke (E.A. Nyawade), monani@uwc.ac.za (M.O. Onani).
} 
biological activity.

The biological activity of TSC derivatives and their metal complexes depend on the parent aldehyde and ketone, and the central metal ion of the complexes. Heterocyclic TSCs and their Pd(II) and Pt(II) complexes exhibit a great variety of biological activities against various tumors $[13,14]$ viruses $[15,16]$, fungi [17], 18bacteria [15,18], protozoa $[12,19,20]$, malaria [21], and convulsions [22].

The cinnamaldehyde (CIN), a naturally occurring phytochemical compound, possesses highly significant properties such as anti-inflammatory, oxidative and anti-oxidative making it a suitable candidate for anticancer drugs. It has been shown to exert chemopreventive activity against several types of human cancer cells by inducing apoptosis and thus regulating cancer cell invasion and metastasis [23]. CIN has found application in treating various types of cancer, including breast, prostate, colon, leukemia, liver, and oral cancers [24,25]. CIN has also been shown to reduce the spontaneous mutant frequency in Salmonella typhimurium strain TA104 and Escherichia coli by $50 \%$ [26,27]. Owing to the potential of CIN and derivatives as therapeutic agents, researches on chemical syntheses and modifications have been carried out to gain chemical entities with more potent bioactivity and favorable druggability $[28,29]$.

It is worth noting that coordination of ligands to metals give them a three dimensional orientation which aid their specific molecule recognition thus improving their biological activity [30,31].

The fact that TSCs are good chelating ligands with great pharmacological activities and that their coordination to the Pd metal center may trigger or enhance their biological activity, greatly inspired this study. New TSCs based thiophene derivative (a heterocyclic ketone) and CIN, coordinated to Pd(II) ion, were prepared and their mode of coordination and anticancer activities determined. We therefore herein report for the first time the synthesis and cytotoxicity studies of Pd(II) complexes of 2-acetyl-5-methyl thiophene TSCs and CIN TSCs.

\section{Materials and methods}

\subsection{General methods and materials}

All reactions herein were performed under inert conditions using Schlenk techniques and monitored by thin layer chromatography using Merck silica gel $60 \mathrm{~F}_{254}$ plates. 2-Acetyl-5-methylthiophene (AMT), $\mathrm{CIN}, \mathrm{TSC}-\mathrm{H}$ and 4-methyl-3-thiosemicarbazide $\left(\mathrm{TSC}-\mathrm{CH}_{3}\right)$ were purchased from Sigma Aldrich and used without further purification. The organic solvents; ethanol, methanol, methylene chloride, diethyl ether were obtained from Sigma Aldrich and purified by standard techniques. Melting points were determined using a Stuart Scientific SMP 10 apparatus. Solid state Fourier Transform infrared (FT-IR) on potassium bromide (KBr) were recorded on a Perkin Elmer Spectrum Two model FT-IR Spectrophotometer $\left(4000-400 \mathrm{~cm}^{-1}\right) .{ }^{1} \mathrm{H}$ and ${ }^{13} \mathrm{C}$ NMR of the compounds in deuterated dimethylsulfoxide (DMSO- $d_{6}$ ) using trimethyl silane as an internal standard was recorded at $25{ }^{\circ} \mathrm{C}$ on a Bruker Avance III HD Nanobay $400 \mathrm{MHz}$ NMR spectrometer equipped with a $5 \mathrm{~mm}$ BBO probe. Electronic spectra were recorded on a Thermo Scientific Nicolet Evolution 100 Ultraviolet visible (UV-Vis) Spectrophotometer. Elemental analyses were performed on a LECO CNHS-932 micro-analyzer at the Central Analytical Facilities, Stellenbosch University, South Africa. Conductivity measurements were performed on a HANNA EC 215 conductivity meter. The single crystal structures of L2 and L4 were obtained from a Bruker Smart KAPPA APEXII DUO diffractometer with graphite monochromated Mo Karadiation ( $\mathrm{k}=0.71073 \AA$ ) at Rutgers, the State University of New Jersey, Newark, USA. The metal precursor $\left[\mathrm{Pd}(\mathrm{COD}) \mathrm{Cl}_{2}\right]$ (COD = 1,5-cyclooctadiene) was prepared following previously reported methods [32,33].

\subsection{Syntheses}

2.2.1. Synthesis of 2-acetyl-5-methylthiophene TSCs ligands L1 and L2 (2E)-2-[1-(5-Methyl-2-thienyl)ethylidene] hydrazinecarbothioamide (AMT-C $=N-T S C H), L 1$

TSC-H, (1.0 mmol; $91.13 \mathrm{mg})$ was dissolved in $10 \mathrm{~mL}$ methanol in a Schlenk tube and stirred under reflux for $30 \mathrm{~min}$. To the methanolic solution of TSC-H, a solution of AMT $(0.0 \mathrm{mmol} ; 140.2 \mathrm{mg})$ in prepared in $10 \mathrm{~mL}$ methanol was added drop wise while stirring continuously. Two drops of $\mathrm{H}_{2} \mathrm{SO}_{4}$ was added to the mixture and stirred under reflux for $2 \mathrm{hr}$. The solution turned pale yellow. A whitish cream precipitate appeared on cooling. The mixture was filtered by use of a cannula and the residue was washed with cold methanol. The residue was dried under reduced pressure for $3 \mathrm{~h}$ and characterized by FTIR, NMR, UV-vis and elemental analysis. The yield was $67.0 \%(142.92 \mathrm{mg})$ and melting point was found to be $172-174{ }^{\circ} \mathrm{C}$.

Analysis:

Molecular formula: $\mathrm{C}_{8} \mathrm{H}_{11} \mathrm{~N}_{3} \mathrm{~S}_{2}$. Elemental analysis: Calculated: C; 45.04, H; 5.20, N; 19.70, S; 30.06\%. Found: C; 45.30, H; 5.30, N; 20.16, S; $30.32 \% .{ }^{1} \mathrm{H}$ NMR (400 MHz, DMSO- $d_{6}$ ): $\delta 2.42$ (s, 3H), $\delta 2.27$ (s, 3H), $\delta 6.78(\mathrm{~m}, J=1.48 \mathrm{~Hz}, 1 \mathrm{H}$ (thiophene)), $\delta 7.31(\mathrm{~d}, J=3.62 \mathrm{~Hz}, 1 \mathrm{H}$ (thiophene)), $\delta 8.28$ (s, $1 \mathrm{H}(-\mathrm{NH})) . \delta 10.39(\mathrm{~s}, 1 \mathrm{H}(\mathrm{NNH})) .{ }^{13} \mathrm{C}$ NMR (400 MHz, DMSO- $\left.d_{6}\right): \delta 178.9(\mathrm{C}=\mathrm{S}), \delta 145.5(\mathrm{C}=\mathrm{N}), \delta 142.9(\mathrm{C}-\mathrm{S}), \delta$ $140.9(\mathrm{C}-\mathrm{S}), \delta 128.8(\mathrm{C}=\mathrm{C}), \delta 126.8(\mathrm{C}=\mathrm{C}), \delta 15.8\left(\mathrm{CH}_{3}\right), \delta 14.8$ $\left(\mathrm{CH}_{3}\right)$. IR (KBr, solid state; $\left.\mathrm{cm}^{-1}\right): \nu(\mathrm{H}-\mathrm{N}-\mathrm{H}) 3366,3263, \nu(\mathrm{NN}-\mathrm{H})$ 3119, $\nu(-\mathrm{C}=\mathrm{N})$ 1629, 1521, $\nu(\mathrm{C}=\mathrm{S})$ 1286, $\nu(\mathrm{C}-\mathrm{S})$ thiophene 796 $\nu(-\mathrm{N}-\mathrm{N})$ 993. UV-Vis (DMSO), $\lambda_{\max }, \mathrm{nm}\left(\varepsilon, \mathrm{M}^{-1} \mathrm{~cm}^{-1}\right) 341$ (1030).

(2E)- $N$-Methyl-2-[1-(5-Methyl-2-thienyl)ethylidene]hydrazinecarbothioamide (AMT- $-\mathrm{C}=\mathrm{N}-\mathrm{TSC}\left(\mathrm{CH}_{3}\right)$ ), $\mathbf{L 2}$

The same procedure described for the synthesis of ligand $\mathbf{L 1}$ was followed in the preparation of ligand L2. Solutions of TSC- $\mathrm{CH}_{3}$ (1.0 mmol, $105.2 \mathrm{mg}$ ) and AMT (1.0 mmol, $140.2 \mathrm{mg})$ in $10 \mathrm{~mL}$ methanol were used. A whitish cream solid obtained in $71 \%$ yield was characterized by elemental analysis, FTIR, NMR and UV-vis. It melted at a temperature of $176{ }^{\circ} \mathrm{C}$. Crystals of ligand $\mathbf{L} 2$ were grown by dissolving the whitish cream solid in ethanol followed by addition of a layer of diethyl ether onto the solution. The solution was left undisturbed for $48 \mathrm{~h}$. Whitish cream needle shaped crystals of ligand L2 were obtained.

Analysis:

Molecular formula: $\mathrm{C}_{9} \mathrm{H}_{13} \mathrm{~N}_{3} \mathrm{~S}_{2}$. Elemental analysis: Calculated: C; 47.55, H; 5.76, N; 18.48, S; 28.21\%. Found: C; 47.70, H; 5.70, N; 18.01, $\mathrm{S} ; 27.88 \% .{ }^{1} \mathrm{H}$ NMR (400 MHz, DMSO- $\left.d_{6}\right): \delta 2.26\left(\mathrm{~s}, 3 \mathrm{H}, \mathrm{CH}_{3}\right), \delta 2.43$ (s, $\left.3 \mathrm{H}, \mathrm{CH}_{3}\right), \delta 3.02\left(\mathrm{~s}, J=4.62,3 \mathrm{H}, \mathrm{NCH}_{3}\right), \delta 6.78(\mathrm{q}, J=1.50 \mathrm{~Hz}, 1 \mathrm{H}$ (thiophene)), $\delta 7.30(\mathrm{~d}, J=3.61 \mathrm{~Hz}, 1 \mathrm{H}$ (thiophene)), $\delta 7.97$ (d, $J=4.35 \mathrm{~Hz}, 1 \mathrm{H}(-\mathrm{NH})) . \delta 10.25(\mathrm{~s}, 1 \mathrm{H}(\mathrm{NNH})) .{ }^{13} \mathrm{C} \mathrm{NMR}(400 \mathrm{MHz}$, DMSO- $\left.d_{6}\right): \delta 178.8(\mathrm{C}=\mathrm{S}), \delta 145.3(\mathrm{C}=\mathrm{N}), \delta 142.7(\mathrm{C}-\mathrm{S}), \delta 140.9$ $(\mathrm{C}-\mathrm{S}), \delta 128.5(\mathrm{C}=\mathrm{C}), \delta 126.5(\mathrm{C}=\mathrm{C}), \delta 31.5\left(\mathrm{CH}_{3}\right), \delta 15.7\left(\mathrm{CH}_{3}\right), \delta$ $14.8\left(\mathrm{CH}_{3}\right)$. IR (KBr, solid state; $\left.\mathrm{cm}^{-1}\right): \nu(-\mathrm{N}-\mathrm{H}) 3331, \nu(\mathrm{NN}-\mathrm{H}) 3246$, $\nu\left(\mathrm{H}_{2} \mathrm{C}-\mathrm{H}\right) \quad 2924, \nu(-\mathrm{C}=\mathrm{N}) \quad 1541, \quad 1506, \nu(\mathrm{C}=\mathrm{S}) \quad 1236, \nu(-\mathrm{N}-\mathrm{N})$ $1042, \nu(\mathrm{C}-\mathrm{S})$ thiophene658. UV-Vis (DMSO), $\lambda_{\max }, \mathrm{nm}\left(\varepsilon, \mathrm{M}^{-1} \mathrm{~cm}^{-1}\right)$ 342 (1000).

\subsubsection{Synthesis of CIN TSCs, L3 and L4}

(2E)-2-[(2E)-3-Phenyl-2-propen-1-ylidene]hy-

drazinecarbothioamide ( $\mathrm{CIN}-\mathrm{C}=\mathrm{N}-\mathrm{TSCH}), \mathbf{L 3}$

TSC-H (1.0 mmol, $91.13 \mathrm{mg})$ in $10 \mathrm{~mL}$ dry methanol was added in a clean Schlenk tube and stirred under reflux for $30 \mathrm{~min} .10 \mathrm{~mL}$ methanolic solution of CIN (1.0 mmol, $0.13 \mathrm{~mL}$ ) was slowly added to the solution followed by a drop of conc. $\mathrm{H}_{2} \mathrm{SO}_{4}$. The mixture was stirred under reflux for $2 \mathrm{~h}$ after which it was allowed to cool to room temperature. A pale yellow precipitate formed, mixture was filtered via a canula, washed with cold methanol and dried under reduced pressure for $3 \mathrm{~h}$. The solid obtained in 70\% yield melted at a temperature of $121.0^{\circ} \mathrm{C}$.

Analysis: 
Molecular formula: $\mathrm{C}_{10} \mathrm{H}_{11} \mathrm{~N}_{3} \mathrm{~S}$. Elemental analysis: Calculated: C; 58.51, H;5.40, N; 20.47, S; 15.62\%. Found: C; 58.40, H; 5.81, N; 19.98, $\mathrm{S} ; 15.27 \% .{ }^{1} \mathrm{H}$ NMR (400 MHz, DMSO, $\mathrm{d}_{6}$ ): $\delta 11.4$ (s, $1 \mathrm{H}(\mathrm{NNH})$ ), $\delta 8.19$ $(\mathrm{s}, 1 \mathrm{H}(-\mathrm{NH})), \delta 7.90(\mathrm{~d}, J=9.21 \mathrm{~Hz}, 1 \mathrm{H}(\mathrm{N}=\mathrm{CH})), \delta 7.62(\mathrm{~s}, 1 \mathrm{H}$ $(-\mathrm{NH})$ ), $\delta 7.56$ (d, $J=7.28 \mathrm{~Hz}, 2 \mathrm{H}($ phenyl)), $\delta 7.37$, (m, $J=8.50 \mathrm{~Hz}$, $3 \mathrm{H}$ (phenyl)), $\delta 7.0$ (d, $J=16.14 \mathrm{~Hz}, 1 \mathrm{H}($ allyl)), $\delta 6.88$, (dd, $J=8.06 \mathrm{~Hz}$, $1 \mathrm{H}\left(\right.$ allyl)). ${ }^{13} \mathrm{C}$ NMR (400 MHz, $\left.\mathrm{CD}_{3} \mathrm{OD}\right): \delta 178.1(\mathrm{C}=\mathrm{S}), \delta 145.2(\mathrm{C}=$ $\mathrm{N}), \quad \delta$ 136.3, 129.4, 129.3, 127.4, (C(Phenyl)), 139.3, 125.5 $\left(\mathrm{C}=\mathrm{C}(\right.$ allyl)$)$. IR $\left(\mathrm{KBr}\right.$, solid state; $\left.\mathrm{cm}^{-1}\right): \nu(\mathrm{H}-\mathrm{N}-\mathrm{H}) 3415,3254$, $\nu(\mathrm{NN}-\mathrm{H}), 3147, \nu$ (phenyl $-\mathrm{C}-\mathrm{H}) \quad 3000, \nu(-\mathrm{C}=\mathrm{N})$ 1588,1521, $\nu(\mathrm{C}=\mathrm{S})$ $1277, \nu(-\mathrm{N}-\mathrm{N})$ 1085. UV-Vis (DMSO), $\lambda_{\max }, \mathrm{nm}\left(\varepsilon, \mathrm{M}^{-1} \mathrm{~cm}^{-1}\right) 345$ (1470), 258sh (1248).

(2E)- $N$-Methyl-2-[(2E)-3-Phenyl-2-propen-1-ylidene]hydrazinecarbothioamide $\mathrm{CIN}-\mathrm{C}=\mathrm{N}-\mathrm{TSC}\left(\mathrm{CH}_{3}\right)$ ), $\mathbf{L} 4$

The same procedure described for the ligand $\mathbf{L} 3$ was followed in the preparation of ligand L4. Solutions of AMT (1.0 mmol, $105.2 \mathrm{mg}$ ) and CIN (1.0 mmol, $0.13 \mathrm{~mL}$ ) in $10 \mathrm{~mL}$ methanol were used. A yellow powder obtained in $68 \%$ yield was characterized by elemental analysis, FTIR, NMR and UV-vis. It melted at a temperature of $168-170{ }^{\circ} \mathrm{C}$. Crystals suitable for single crystal x-ray diffraction was obtained by following the procedure described for crystal growth in Section 2.2.1 Pale yellow needle-shaped crystals were obtained.

Analysis:

Molecular formula: $\mathrm{C}_{11} \mathrm{H}_{13} \mathrm{~N}_{3}$ S. Elemental analysis: Calculated: C; 60.24, H; 5.97, N; 19.16, S; 14.64\%. Found: C; 60.41, H; 5.97, N; 19.01, $\mathrm{S} ; 14.69 \% .{ }^{1} \mathrm{H}$ NMR (400 MHz, DMSO- $d_{6}$ ): $\delta 11.46$ (s, $1 \mathrm{H}(\mathrm{NNH})$ ), $\delta 8.30$ (d, $J=4.49 \mathrm{~Hz}, 1 \mathrm{H}(-\mathrm{NH})), \delta 7.91(\mathrm{~d}, \mathrm{~J}=9.20,1 \mathrm{H}(\mathrm{N}=\mathrm{CH})), \delta$ 7.55(d, $J=7.33 \mathrm{~Hz}, 2 \mathrm{H}$ (phenyl)), $\delta 7.37$, (m, $J=35 \mathrm{~Hz}, 3 \mathrm{H}($ phenyl)), $\delta$ 7.0 (d, $J=16.13 \mathrm{~Hz}, 1 \mathrm{H}($ allyl)), $\delta 6.87$ (dd, $J=8.44 \mathrm{~Hz}, 1 \mathrm{H}($ allyl)), $\delta$ 2.98 (d, $\left.J=4.55 \mathrm{~Hz}, 3 \mathrm{H}\left(\mathrm{CH}_{3}\right)\right) .{ }^{13} \mathrm{C}$ NMR $\left(400 \mathrm{MHz}\right.$, DMSO $\left.-\mathrm{d}_{6}\right): \delta$ $177.9(\mathrm{C}=\mathrm{S}), \quad \delta 144.7 \quad(\mathrm{C}=\mathrm{N}), \quad \delta \quad 136.6,129.4,129.3,127.3$, (C(Phenyl)), 139.1, 125.5 ( $\mathrm{C}=\mathrm{C}\left(\right.$ allyl)), $31.3\left(\mathrm{~N}-\mathrm{CH}_{3}\right)$ IR ( $\mathrm{KBr}$, solid state; $\left.\mathrm{cm}^{-1}\right): \nu(-\mathrm{N}-\mathrm{H}) 3353, \nu(\mathrm{NN}-\mathrm{H})$ 3164, $v($ phenyl-C-H) 2991, $\nu(-\mathrm{C}=\mathrm{N})$ 1532, $\nu(\mathrm{C}=\mathrm{S})$ 1256, 748, $\nu(-\mathrm{N}-\mathrm{N})$ 1084. UV-Vis (DMSO), $\lambda_{\max }, \mathrm{nm}\left(\varepsilon, \mathrm{M}^{-1} \mathrm{~cm}^{-1}\right) 344$ (1487), 361sh (1163).

\subsubsection{Synthesis of the Pd(II) complexes}

The TSC ligand was generally dissolved in methanol in a Schlenk tube and stirred for $10 \mathrm{~min}$ at room temperature. A solution of Pd (COD) $\mathrm{Cl}_{2}$ in methylene chloride was added to the contents of the Schlenk tube drop wise as the mixture was continuously stirred. An orange colored precipitate appeared almost immediately. The mixture was stirred at room temperature for $4 \mathrm{~h}$ and the solid was allowed to settle at the bottom of the Schlenk tube. The mixture was filtered; the residue was washed with cold methanol, rinsed with diethyl ether and dried under reduced pressure. The products were characterized by FTIR, UV-vis, ${ }^{1} \mathrm{H}$ NMR, melting point and elemental analysis.

2.2.3.1. Synthesis of complex C1, Pd(L1)Cl. The ligand L1 $(0.5 \mathrm{mmol}$, $106.66 \mathrm{mg}$ ) was dissolved in methanol in a Schlenk tube at room temperature and stirred. An equimolar amount of $\mathrm{Pd}(\mathrm{COD}) \mathrm{Cl}_{2}$ solution in methylene chloride was added to the Schlenk tube. The rest of the procedure as described in Section 2.2.3 was followed. A dark orange precipitate was formed in $83 \%$ yield. The solid decomposes at $248{ }^{\circ} \mathrm{C}$.

Analysis:

Molecular formula: $\mathrm{C}_{8} \mathrm{H}_{10} \mathrm{ClN}_{3} \mathrm{PdS}_{2}$. Elemental analysis: Calculated: C; 27.13, H; 2.85, N; 11.86, S; 18.10\%. Found: C; 27.02, H; 2.50, N; 11.69, $\mathrm{s} ; 18.01 \% .{ }^{1} \mathrm{H}$ NMR (400 MHz, DMSO- $\left.d_{6}\right): \delta 2.36\left(\mathrm{~s}, 3 \mathrm{H}\left(\mathrm{CH}_{3}\right)\right), \delta$ 2.45 (s, $3 \mathrm{H},\left(\mathrm{CH}_{3}\right.$ thiophene)), $\delta 6.87$ (d, $J=3.92 \mathrm{~Hz}, 1 \mathrm{H}$ (thiophene)), $\delta 7.4554$ (d, $J=3.96 \mathrm{~Hz}, 1 \mathrm{H}$ (thiophene)), $\delta 9.23\left(\mathrm{~s}, 2 \mathrm{H}\left(\mathrm{NH}_{2}\right)\right.$. IR $(\mathrm{KBr}$, solid state; $\left.\mathrm{cm}^{-1}\right): \nu(\mathrm{H}-\mathrm{N}-\mathrm{H})$ 3342, $\nu(-\mathrm{C}=\mathrm{N})$ 1624,1530, $(\mathrm{N}-\mathrm{N})$ 1046, $v(\mathrm{C}-\mathrm{S})$ thiophene 646, $v(\mathrm{Pd}-\mathrm{N}) 551, \nu(\mathrm{Pd}-\mathrm{S}) 406,478$. UV-Vis (DMSO), $\lambda_{\max } \mathrm{nm},\left(\varepsilon, \mathrm{M}^{-1} \mathrm{~cm}^{-1}\right) 291$ (1589), 342 (1166), 393sh (433), 480sh (218).
$\mathrm{N}-\mathrm{TSC}-\mathrm{CH}_{3}(0.1 \mathrm{mmol}, 22.73 \mathrm{mg})$ and an equimolar amount of the precursor were used as per the procedure described in Section 2.2.3.1 to give an orange solid that turns black and melts at $217{ }^{\circ} \mathrm{C}$ in $89 \%$ yield.

Molecular formula: $\mathrm{C}_{9} \mathrm{H}_{12} \mathrm{Cl}_{2} \mathrm{~N}_{3} \mathrm{PdS}_{2}$. Elemental analysis: Calculated: C; $26.71, \mathrm{H} ; 3.24$, N; 10.38, S; $15.85 \%$. Found: C; 26.65 , H; 3.48, N; 10.36, S; $15.81 \% .{ }^{1} \mathrm{H}$ NMR (400 MHz, DMSO-d $d_{6}$ ): $\delta 2.46$ (s, $3 \mathrm{H}), \delta 2.58$ (s, 3H (thiophene)), $\delta 2.94\left(\mathrm{~s}, 3 \mathrm{H}\left(\mathrm{NCH}_{3}\right)\right), \delta 6.8762$ (d, $J=3.36 \mathrm{~Hz}, 1 \mathrm{H}$ (thiophene)), $\delta 7.49$ (d, $J=3.91 \mathrm{~Hz}, 1 \mathrm{H}$ (thiophene)), $\delta 8.72(\mathrm{~s}, 1 \mathrm{H}(-\mathrm{NH})), \delta 10.26(\mathrm{~s}, 1 \mathrm{H}(\mathrm{NNH}))$. IR $(\mathrm{KBr}$, solid state; $\left.\mathrm{cm}^{-1}\right): \nu(-\mathrm{N}-\mathrm{H}) 3273, v(\mathrm{NN}-\mathrm{H}) 3181, \nu\left(\mathrm{H}_{2} \mathrm{C}-\mathrm{H}\right) 3004,2932, \nu(-\mathrm{C}=$ N) $1565,1514, v(-\mathrm{C}=\mathrm{C}-)$ 1441, 1397, $v(\mathrm{C}=\mathrm{S}) 1229, v(-\mathrm{N}-\mathrm{N}) 1048$, $\nu(\mathrm{C}-\mathrm{S})$ thiophene 536, $\nu(\mathrm{Pd}-\mathrm{N})$ 530, $\nu(\mathrm{Pd}-\mathrm{S})$ 450, 497. UV-Vis (DMSO), $\lambda_{\max } \mathrm{nm},\left(\varepsilon, \mathrm{M}^{-1} \mathrm{~cm}^{-1}\right), 340$ (1472), 393sh (417), 486 (87.2).

2.2.3.3. Synthesis of complex $\mathrm{C3}, \mathrm{Pd}(\mathrm{L} 3)_{2}$. To a methanolic solution of ligand L3 (1.0 mmol, $205.28 \mathrm{mg})$ in a Schlenk tube, a solution of Pd (COD) $\mathrm{Cl}_{2}(0.5 \mathrm{mmol}, 142.76 \mathrm{mg})$ in methylene chloride was added and the rest of the procedure followed as described in Section 2.2.3. An orange solid was obtained in $87 \%$ yield. The solid decomposes at a temperature above $281{ }^{\circ} \mathrm{C}$.

Analysis:

Molecular formula: $\mathrm{C}_{20} \mathrm{H}_{20} \mathrm{~N}_{6} \mathrm{PdS}_{2}$. Elemental analysis: Calculated: C; 46.65, H; 3.91, N; 16.32, S; 12.45\%. Found: C; 46.39, H; 4.09, N; 16.11, $\mathrm{s} ; 12.29 \% .{ }^{1} \mathrm{H}$ NMR (400 MHz, DMSO-d $\left.d_{6}\right): \delta 9.14\left(2 \mathrm{H}, \mathrm{NH}_{2}\right), \delta$ $8.08(\mathrm{~m}, J=5.42 \mathrm{~Hz}, 1 \mathrm{H}(\mathrm{CH}$, allyl)), 7.62 (s, $1 \mathrm{H}(-\mathrm{CH}$, allyl)), $\delta 7.73$ (m, $J=16.10 \mathrm{~Hz}, 5 \mathrm{H}$ (phenyl)). IR (KBr, solid state; $\left.\mathrm{cm}^{-1}\right): \nu(\mathrm{H}-\mathrm{N}-\mathrm{H})$ 3421, 3259, $\nu$ (phenyl-C-H) 2975, 2828, $\nu(-\mathrm{C}=\mathrm{N}) \quad 1583,1513$, $\nu$ (aromatic $-\mathrm{C}=\mathrm{C}) 1481, \nu(-\mathrm{N}-\mathrm{N})$ 977, $\nu(\mathrm{Pd}-\mathrm{N}) 508, \nu(\mathrm{Pd}-\mathrm{S}) 475$. UV-Vis (DMSO), $\lambda_{\max } \mathrm{nm},\left(\varepsilon, \mathrm{M}^{-1} \mathrm{~cm}^{-1}\right.$ ), 303 (1770), 362 (1920), 417 (1412), 486 (97).

2.2.3.4. Synthesis of complex C4, $\mathrm{Pd}\left(\mathrm{L}_{4}\right) \mathrm{Cl}_{2}$. The ligand $\mathrm{L} 4(1.0 \mathrm{mmol}$, $219.31 \mathrm{mg})$ and $\mathrm{Pd}(\mathrm{COD}) \mathrm{Cl}_{2}(1.0 \mathrm{mmol}, 285.51 \mathrm{mg})$ were used and the procedure described in Section 2.2.3.3 followed to give an orange solid in $81 \%$ yield. Solid turns black and decomposes above $235{ }^{\circ} \mathrm{C}$.

Analysis:

Molecular formula: $\mathrm{C}_{11} \mathrm{H}_{13} \mathrm{Cl}_{2} \mathrm{~N}_{3} \mathrm{PdS}$. Elemental analysis: Calculated: C; 33.31, H; 3.30, N; 10.59, S; 8.08\%. Found: C; 33.21, H; 3.44, N; 10.52 , S; 8.07\%. ${ }^{1} \mathrm{H}$ NMR (400 MHz, DMSO, $\left.\mathrm{d}_{6}\right): \delta 11.10(1 \mathrm{H}$ $(\mathrm{NNH}), \delta 8.08(\mathrm{~d}, J=9.61 \mathrm{~Hz}, 1 \mathrm{H}(\mathrm{N}=\mathrm{CH})), \delta 7.62(\mathrm{~m}, J=4.88 \mathrm{~Hz}$, $1 \mathrm{H}(-\mathrm{NH})), \delta 7.63-7.39$ (m, 5H (phenyl)), $\delta 7.32$ (d, $J=7.53 \mathrm{~Hz}, 1 \mathrm{H}$ (allyl)), $\delta 7.28$ (dd, $J=8.44 \mathrm{~Hz}, 1 \mathrm{H}($ allyl)), $\delta 2.83$ (d, $J=8.78 \mathrm{~Hz}, 3 \mathrm{H}$ $\left(\mathrm{CH}_{3}\right)$. IR $\left(\mathrm{KBr}\right.$, solid state; $\left.\mathrm{cm}^{-1}\right): \nu(-\mathrm{N}-\mathrm{H}) 3246, \nu$ (phenyl-C-H) 3010, 2932, $\nu(-\mathrm{C}=\mathrm{N}) 1607,1527 \nu$ (aromatic $-\mathrm{C}=\mathrm{C}) 1445, \nu(\mathrm{C}=\mathrm{S})$ 1165, $\nu(-\mathrm{N}-\mathrm{N})$ [1018], $\nu(\mathrm{Pd}-\mathrm{N})$ 501, $v(\mathrm{Pd}-\mathrm{S})$ 458. UV-Vis (DMSO), $\lambda_{\max } \mathrm{nm},\left(\varepsilon, \mathrm{M}^{-1} \mathrm{~cm}^{-1}\right.$ ), 297 (1271), 370 (1690), 388 (1681), 470 (96.6).

\subsection{Crystal data determination and structure refinement ligands $\mathbf{L} 2$ and $\mathbf{L} 4$}

Crystals fit for single crystal X-ray diffraction studies were grown by layering solutions of the compounds in dry ethanol with a three times excess volume of diethyl ether and allowing it to stand for $48 \mathrm{~h}$. L2 and L4 crystals were selected, glued onto the tip of glass fibers, mounted in a stream of cold nitrogen at 100(1) K and centered in the X-ray beam by using a video camera. Reflections were successfully indexed by an automated indexing routine built in the APEXII program suite [34]. The structures were solved by direct methods using SHELXS [35] and refined [34]. All structures were checked for solvent-accessible cavities using PLATON [36] and the graphics were performed with the DIAMOND [37] visual crystal structure information system software. The absorption correction was based on fitting a function to the empirical transmission surface as sampled by multiple equivalent measurements [34]. The CIF files for the crystals can be obtained from the Cambridge Crystallographic Data Centre (Supplementary Material file). The crystal data and structure refinement for the ligands L2 and L4 are summarized 
Table 1

Crystal data and structure refinement for Ligands L2 and L4.

\begin{tabular}{|c|c|c|c|c|}
\hline & L2 & & L4 & \\
\hline Empirical formula & $\mathrm{C}_{9} \mathrm{H}_{13} \mathrm{~N}_{3} \mathrm{~S}_{2}$ & & $\mathrm{C}_{11} \mathrm{H}_{13} \mathrm{~N}_{3} \mathrm{~S}$ & \\
\hline Formula weight & 227.3 & & 219.30 & \\
\hline Temperature & $100 \mathrm{~K}$ & & $100 \mathrm{~K}$ & \\
\hline Wavelength & $1.54178 \AA$ & & $1.54178 \AA$ & \\
\hline Crystal system & Monoclinic & & Monoclinic & \\
\hline Space group & $\mathrm{P} 21 / \mathrm{c}$ & & $\mathrm{P} 21 / \mathrm{n}$ & \\
\hline \multirow[t]{3}{*}{ Unit cell dimensions $\left(\AA{ }^{\circ}{ }^{\circ}\right)$} & $\mathrm{a}=5.5173(4)$ & $\alpha=90$ & $\mathrm{a}=5.4418(2)$ & $\alpha=90$ \\
\hline & $\mathrm{b}=11.1578(8)$ & $\beta=96.00(2)$ & $\mathrm{b}=9.2819(3)$ & $\beta=92.056(2)$ \\
\hline & $c=18.0817(3)$ & $\gamma=90$ & $c=22.4502(7)$ & $\gamma=90$ \\
\hline Volume & $1106.98(14) \AA^{3}$ & & $1133.27(7) \AA^{3}$ & \\
\hline $\mathrm{Z}$ & 4 & & 4 & \\
\hline Density (calculated) & $1.364 \mathrm{Mg} / \mathrm{m}^{3}$ & & $1.285 \mathrm{Mg} / \mathrm{m}^{3}$ & \\
\hline Absorption coefficient & $4.075 \mathrm{~mm}^{-1}$ & & $2.290 \mathrm{~mm}^{-1}$ & \\
\hline $\mathrm{F}(000)$ & 483.62 & & 466.41 & \\
\hline $\mathrm{h}, \mathrm{klmax}$ & $6,13,21$ & & $6,11,22$ & \\
\hline Nref (reported) & 1954 & & 2004 & \\
\hline Data completeness & 0.970 & & 0.960 & \\
\hline Theta max & 68.116 & & 68.545 & \\
\hline Absorption correction & Numerical & & Numerical & \\
\hline Max. and min. transmission & 0.799 and 0.544 & & 0.843 and 0.396 & \\
\hline $\mathrm{R}$ (reflections) & 0.0267 (1809) & & $0.0331(1892)$ & \\
\hline wR2(reflections) & 0.0691 (1954) & & $0.0814(2004)$ & \\
\hline $\mathrm{S}$ & 1.045 & & 1.099 & \\
\hline Npar & 136 & & 138 & \\
\hline
\end{tabular}

in Table 1.

\subsection{Anticancer activity}

Cytotoxicity of the compounds was tested against human cell lines obtained from American Type Culture Collection (Manassas, United States of America): Caco-2 (colon), HeLa (cervical), Hep-G2 (hepatocellular), MCF-7 (breast), PC-3 (prostate) cancers and MCF-12A (noncancer breast) cells. The cells were cultured in their respective media supplemented with $10 \%$ fetal bovine serum (FBS) and $1 \%$ penicillinstreptomycin cocktail $(100 \mu \mathrm{g} / \mathrm{mL}$ penicillin and $100 \mu \mathrm{g} / \mathrm{mL}$ streptomycin). Caco-2, HeLa, HepG2, and MCF-7 cells were grown in Dulbecco's Modified Eagle Medium (DMEM); MCF-12A in DMEM-F12 containing insulin, EGF and hydrocortisone; while PC-3 cells were cultured in RPMI- 1640 media. The cells were grown at $37{ }^{\circ} \mathrm{C}$ in a $5 \%$ $\mathrm{CO}_{2}$ humidified incubator (Labotech, South Africa). The cells were seeded at $1 \times 10^{5}$ cells $/ \mathrm{mL}$ density in a 96-well plate and incubated at $37{ }^{\circ} \mathrm{C}$ for $24 \mathrm{~h}$. The cells were treated with varying concentrations of compounds $(0-100 \mu \mathrm{g} / \mathrm{mL})$ and incubated at $37{ }^{\circ} \mathrm{C}$ for $24 \mathrm{~h}$. Cytotoxicity of the compounds was assessed by MTTassay, a colorimetric assay that measures the reduction of yellow 3-(4,5-dimethythiazol-2-yl)-2,5-diphenyl tetrazolium bromide (MTT)by mitochondrial succinate dehydrogenase, following manufacturer's instructions. After treatment, $10 \mu \mathrm{L}$ of $5 \mathrm{mg} / \mathrm{mL}$ MTT (Sigma, USA) was added to each well $(100 \mu \mathrm{L} /$ well $)$ and incubated at $37^{\circ} \mathrm{C}$ for $3 \mathrm{~h}$. The insoluble formazan crystals were solubilized by adding $100 \mu \mathrm{L}$ of
DMSO. The reduction of MTT was read at $570 \mathrm{~nm}$ using POLARStar Omega plate reader. Cell viability was calculated using this formula:

$\downarrow$ Cell Viability $=\left(\frac{\text { Average absorbances of treated cells }}{\text { Average absorbances of control }}\right) \times 100 \backslash \%$

The concentration of the compounds that inhibited $50 \%$ cell proliferation $\left(\mathrm{IC}_{50}\right.$ ) on each cell line was estimated using GraphPad Prism software version 5 (GraphPad Software, California, USA).

\section{Results and discussion}

\subsection{Synthesis and characterization of the ligands}

The reactions of 2-acetyl-5-methylthiophene with thiosemicarbazide and 4-methyl-3-thiosemicarbazide in methanol under reflux formed the 2-acetyl-5-methylthiophene TSC ligands L1 and L2 as whitish cream solids, respectively. The CIN TSC ligands L3 and L4 were obtained by the reaction of cinnamaldehyde with thiosemicarbazide and 4-methyl-3-thiosemicarbazide, respectively, in methanol as a solvent under reflux respectively (Fig. 1). The TSC ligands were characterized by FTIR, UV-Vis, ${ }^{1} \mathrm{H}$ and ${ }^{13} \mathrm{C}$ NMR and elemental analysis.

\subsection{1. ${ }^{1} H$ NMR and FTIR analysis}

The IR spectra of the ligands L1 to L4 displayed stretching frequency bands for the $v(\mathrm{C}=\mathrm{N})$ and $v(\mathrm{C}=\mathrm{S})$ in the regions 1584-1521 and 1256-1225 $\mathrm{cm}^{-1}$, respectively. The absence of bands in the

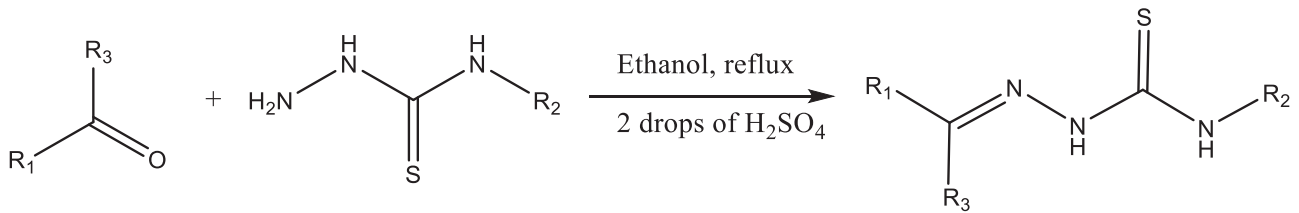

Ligand $\mathbf{L 1} \& \mathbf{L} 2$<smiles>[R7]c1ccc(I)s1</smiles>

$\mathrm{R}_{3}-\mathrm{CH}_{3}$
Ligand L3 \& L4<smiles>[R]C=Cc1ccccc1</smiles>

Ligand L1 \& L3: $\mathrm{R}_{2}=\mathrm{H}$

Ligand $\mathbf{L} 2$ \& L4: $\mathrm{R}_{2}=\mathrm{CH}_{3}$

$\mathrm{R}_{3}-\mathrm{H}$

Fig. 1. General reaction scheme for the synthesis of ligands L1, L2, L3 and L4. 


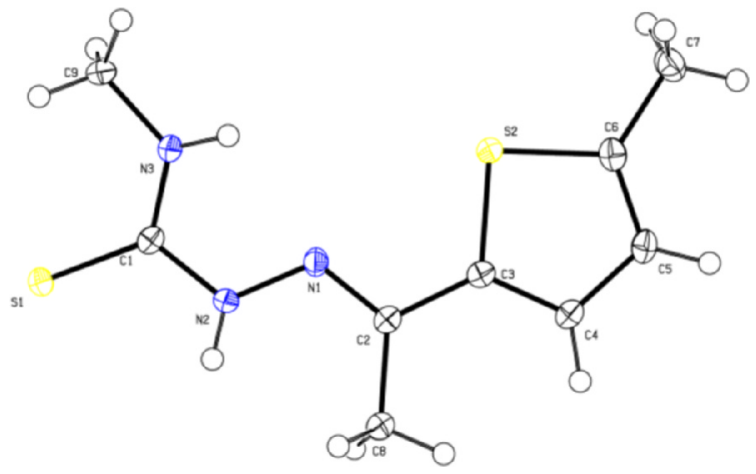

Fig. 2. Ligand L2 in asymmetric unit, showing the atom-numbering scheme. Displacement ellipsoids are drawn at the 50\% probability level.

carbonyl stretching frequency $\nu(C=O)$ in the region $1690-1650 \mathrm{~cm}^{-1}$ and appearance of the imine stretching frequencies in the IR spectra of the ligands indicated that the imine bond was actually formed by condensation. The ${ }^{1} \mathrm{H}$ NMR spectra of TSCs L3 and L4 exhibited a signal associated with the imine proton $\mathrm{C}=\mathrm{NH}$ at $7.9 \mathrm{ppm}$, approximately $1.77 \mathrm{ppm}$ upfield compared to the absent carbonyl proton $\mathrm{HC}=\mathrm{O}$ signal of the cinnamaldehyde ( $9.69 \mathrm{ppm})$, a confirmation that the imine bond was actually formed. The elemental analyses data further confirmed the chemical composition of the TSC. Since thiosemicarbazones have the thioamine functional group $-\mathrm{NH}-\mathrm{C}(\mathrm{S})$, they are capable of exhibiting the thione-thiol tautomeric forms. They can therefore exist as thiols or thiones or a mixture of both [38]. The absence of absorption bands associated with the $-\mathrm{S}-\mathrm{H}$ vibration in the region $2600-2500 \mathrm{~cm}^{-1}$ confirmed that the thione form of the synthesized TSCs is predominant in the solid state $[39,40]$. This is further confirmed by the single crystal XRD structures of L2 and L4 (Figs. 2 and 3). The ${ }^{1} \mathrm{H}$ NMR in DMSO- $\mathrm{d}_{6}$ of TSCs L1 and L2 exhibited a proton signal at 10.32 and 10.24 ppm respectively while L3 and L4 exhibited a proton signal at 11.40 and $11.42 \mathrm{ppm}$ respectively; the proton signals are attributed to the $\mathrm{N}-\mathrm{NH}$ proton. A proton signal at $4.00 \mathrm{ppm}$ attributable to the $-\mathrm{SH}$ proton was absent [8], a clear indication that the TSCs existed as the thione tautomer even in the presence of a solvent as polar as DMSO [8]. TSCs can also exist in $Z$ and $E$-isomeric forms or as a mixture of both isomers in solution. The ${ }^{1} \mathrm{H}$ NMR signals observed in the 10.24-11.42 ppm range are attributed to the hydrazine $\mathrm{N}-\mathrm{NH}$ protons falls within the literature range of 9.00-12.00 ppm reported for the $E$-isomer [8]. The absence of proton signals in the range of $14.00-15.00 \mathrm{ppm}$, normally associated with the hydrazine $\mathrm{N}$-NH protons in the $Z$-isomer, further confirmed that the TSC ligands existed as E-isomers in the DMSO solution $[8] .{ }^{13} \mathrm{C}$

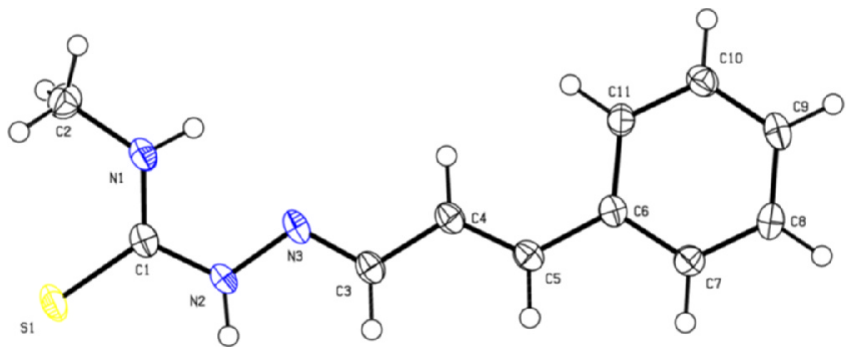

Fig. 4. Crystal structure of L4 with displacement ellipsoids drawn at the $50 \%$ probability level.

carbon signals observed in the range 177.9-178.9 ppm and 44.5-142.5 ppm attributed to the thione $\mathrm{C}=\mathrm{S}$ and imine $\mathrm{C}=\mathrm{N}$ carbon atoms respectively further confirms the formation and existence of the TSCs in the thione tautomer. The NMR and FT-IR results therefore suggest that the thiosemicarbazone ligands exist as $\mathrm{E}$ form of the thione. It is worth noting that the crystal structure of the ligands reveal the existence of the ligands in the $E$-isomers (Figs. 2 and 4).

\subsubsection{Crystal structures of ligands $\mathbf{L} 2$ and $\mathbf{L} 4$}

A few selected geometric parameters for the crystal structures of $\mathbf{L 2}$ and $\mathbf{L} \mathbf{4}$ are summarized in Table 2.

The ligand $\mathbf{L} 2$ crystallizes as whitish cream needle shaped crystals with four molecules in the asymmetric unit. The crystal structure of the ligand L2 is represented in Fig. 2. The crystal belongs to monoclinic crystal class and space group P 21/c. The crystal data is given in Table 1 . The bond lengths and bond angles (Table 2) of the four molecules in a unit cell are equal and are in agreement with values reported for analogous molecules, 1-(Thiophen-2-yl)ethanone TSC [41-43]. The TSC fragment is close to being planar with the maximum deviation from planarity being $0.0435 \AA$ for atom C(1). The maximum deviation from planarity for the thiophene fragment is $0.045 \AA$ at atom $\mathrm{C}(5)$. The thiophene fragment's torsion angles are $\mathrm{S}$ $(2)-\mathrm{C}(6)-\mathrm{C}(5)-\mathrm{C}(4)=0.9(2)^{\circ}$ and $\mathrm{S}(2)-\mathrm{C}(3)-\mathrm{C}(4)-\mathrm{C}(5)=-0.0(2)^{\circ}$ further confirms planarity of the thiophene ring. The torsion angles $177.3(1)^{\circ}$ and $168.8(1)^{\circ}$ for $\mathrm{N}(2)-\mathrm{N}(1)-\mathrm{C}(2)-\mathrm{C}(3)$ and $\mathrm{S}(1)-\mathrm{C}(1)-\mathrm{N}$ (2)-N(1) respectively, suggests that the TSC fragment has an extended conformation which may allow for intramolecular N(3)-H(3) N(1) hydrogen bond formation, and generation of a 5-member ring motif. However the crystal packing does not display the anticipated N(3)-H(3) $\mathrm{N}(1)$ intramolecular hydrogen bonds. The molecules are held together by a network of interactions which include hydrogen bonds $\mathrm{S}(1) \mathrm{H}$ $(2)-\mathrm{N}(2), \mathrm{S}(1) \mathrm{H}(8 \mathrm{~A})-\mathrm{C}(8), \mathrm{S}(1) \mathrm{H}(3)-\mathrm{N}(3)$ and $\mathrm{N}(3) \mathrm{H}(8 \mathrm{~A})-\mathrm{C}(8)$;
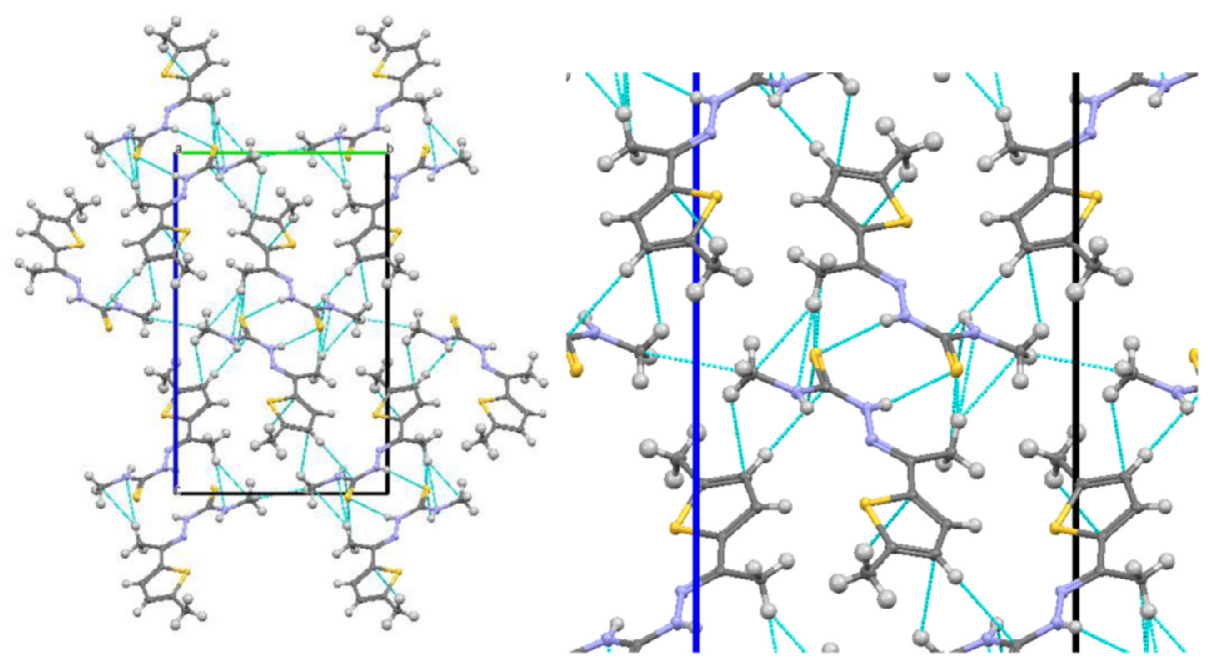

Fig. 3. Crystal packing diagram of $\mathbf{L} 2$ as viewed along the crystallographic a-axis. Intermolecular interactions are indicated by dashed lines. 
Table 2

Geometric parameters of ligands L2 and L4.

\begin{tabular}{|c|c|c|c|}
\hline \multicolumn{4}{|c|}{ Bond distance in Angstroms ( $(\AA)$} \\
\hline L2 & L4 & & \\
\hline $\mathrm{C}(2)^{-} \mathrm{N}(1)$ & $1.292(2)$ & $C(3)-N(3)$ & $1.290(2)$ \\
\hline $\mathrm{N}(1)-\mathrm{N}(2)$ & $1.376(2)$ & $\mathrm{N}(3)-\mathrm{N}(2)$ & $1.376(2)$ \\
\hline $\mathrm{N}(2)-\mathrm{C}(1)$ & $1.361(2)$ & $N(2)-C(1)$ & $1.355(2)$ \\
\hline$C(1)^{-} \mathrm{S}(1)$ & $1.686(2)$ & $\mathrm{C}(1)^{-} \mathrm{S}(1)$ & $1.695(2)$ \\
\hline $\mathrm{C}(1)^{-} \mathrm{N}(3)$ & $1.330(2)$ & $\mathrm{C}(1)^{-} \mathrm{N}(1)$ & $1.324(2)$ \\
\hline $\mathrm{N}(3)-\mathrm{C}(9)$ & $1.443(2)$ & $\mathrm{N}(1)-\mathrm{C}(2)$ & $1.453(2)$ \\
\hline \multicolumn{4}{|l|}{ Bond angles in degrees $\left({ }^{\circ}\right)$} \\
\hline L2 & L4 & & \\
\hline$C(2)-N(1)-N(2)$ & $118.3(1)$ & $\mathrm{C}(3)-\mathrm{N}(3)-\mathrm{N} 2$ & $115.8(1)$ \\
\hline $\mathrm{N}(1)-\mathrm{N}(2)-\mathrm{C}(1)$ & $118.2(1)$ & $N(3)-N(2)-C(1)$ & $118.8(1)$ \\
\hline $\mathrm{C}(1)^{-} \mathrm{N}(3)^{-} \mathrm{C}(9)$ & $124.5(1)$ & $\mathrm{C}(1)^{-} \mathrm{N}(1)^{-} \mathrm{C}(2)$ & $124.7(1)$ \\
\hline $\mathrm{N}(2)-\mathrm{C}(1)-\mathrm{N}(3)$ & $115.8(1)$ & $\mathrm{N}(2)-\mathrm{C}(1)-\mathrm{N}(1)$ & $116.4(1)$ \\
\hline $\mathrm{N}(2)-\mathrm{C}(1)-\mathrm{S}(1)$ & $120.2(1)$ & $\mathrm{N}(1)-\mathrm{C}(1)-\mathrm{S}(1)$ & $124.2(1)$ \\
\hline$N(3)^{-C}(1)^{-S}(1)$ & $123.9(1)$ & $\mathrm{N}(2)-\mathrm{C}(1)-\mathrm{S}(1)$ & $119.5(1)$ \\
\hline \multicolumn{4}{|c|}{ Torsion angles in degrees $\left({ }^{\circ}\right)$} \\
\hline Ligand L2 & L4 & & \\
\hline $\mathrm{C}(2)-\mathrm{N}(1)-\mathrm{N}(2)-\mathrm{C}(1)$ & $-179.9(1)$ & $\mathrm{C}(3)-\mathrm{N}(3)-\mathrm{N}(2)-\mathrm{C}(1)$ & $177.7(1)$ \\
\hline $\mathrm{N}(1)-\mathrm{N}(2)-\mathrm{C}(1)-\mathrm{S}(1)$ & $168.8(1)$ & $\mathrm{N}(3)-\mathrm{N}(2)-\mathrm{C}(1)-\mathrm{S}(1)$ & $176.8(1)$ \\
\hline $\mathrm{N}(1)^{-} \mathrm{N}(2)^{-} \mathrm{C}(1)^{-} \mathrm{N}(3)$ & $-10.1(2)$ & $\mathrm{N}(3)^{-} \mathrm{N}(2)^{-} \mathrm{C}(1)^{-} \mathrm{N}(1)$ & $-4.6(2)$ \\
\hline $\mathrm{N}(2)-\mathrm{C}(1)^{-} \mathrm{N}(3)-\mathrm{C}(9)$ & $-1.3(2)$ & $\mathrm{N}(2)-\mathrm{C}(1)^{-} \mathrm{N}(1)-\mathrm{C}(2)$ & $180.0(2)$ \\
\hline$S(2)-C(6)-C(5)-C(4)$ & $0.9(2)$ & & \\
\hline$S(2)-C(3)-C(4)-C(5)$ & $-0.0(2)$ & & \\
\hline $\mathrm{N}(2)^{-} \mathrm{N}(1)^{-} \mathrm{C}(2)^{-} \mathrm{C}(3)$ & $177.3(1)$ & & \\
\hline
\end{tabular}

$\pi^{-}$hydrogen interactions $\mathrm{C}(5) \mathrm{H}(9 \mathrm{~A})-\mathrm{C}(9)$, and $\mathrm{C}(1) \mathrm{H}(5 \mathrm{~A})-\mathrm{C}(5)$; and Van de Waals forces C(8) S(1), C(9) (9) thereby forming a three dimensional lattice structure (Fig. 3). Two adjacent molecules in the crystal lattice are joined together by $\mathrm{S}(1) \mathrm{H}(2)-\mathrm{N}(2)$ hydrogen bonds forming inversion dimmers. The $\mathrm{C}(1)-\mathrm{N}(2)$ bond distance, $1.361 \AA$, is longer than the $\mathrm{C}(2)-\mathrm{N}(1)$ bond distance, $1.282 \AA$; a clear indication that an imine bond exists in ligand $\mathbf{L 2}$.

The ligand $\mathbf{L} 4$ formed needle shaped monoclinic crystals in P 21/n space group with four molecules in a unit cell. Fig. 4 gives an illustration of the crystal structure.

The benzene ring is planar with a slight variation in the torsion angles ranging from $-0.14^{\circ}$ to $-0.84^{\circ}$. The TSC fragment is fairly planar with torsion angles of $177.7(1)^{\circ}$ and $-4.6(2)^{\circ}$ for $\mathrm{C}(3)-\mathrm{N}(3)-\mathrm{N}$ (2)-C(1) and $\mathrm{N}(3)-\mathrm{N}(2)-\mathrm{C}(1)-\mathrm{N}(1)$ respectively, The benzene ring is trans-related to the thiosemicarbarzone fragment about $\mathrm{C}(3)=\mathrm{C}(4)$ double bond. The bond distances and bond angles are generally the same as those reported in literature [44]. Bond angles, torsion angles and bond distances for ligands $\mathbf{L} \mathbf{2}$ and $\mathbf{L} \mathbf{4}$ are summarized in Table 2. Intermolecular interactions $\mathrm{S}(1) \mathrm{N}(2)$ and $\mathrm{S}(1) \mathrm{H}(2)-\mathrm{N}(2)$ between two adjacent molecules related to each other by inversion lead to formation of centrosymmetric dimmers. The crystal lattice is held together by a network of interactions shown in Fig. 5.

\subsection{Synthesis and characterization of the Pd(II) complexes}

The Pd(II) complexes were synthesized by the reaction of the TSC ligands with $\left[\mathrm{Pd}(\mathrm{COD}) \mathrm{Cl}_{2}\right]$ in the ratio of $1: 1$ for complexes $\mathbf{C 1}, \mathbf{C 2}$ and $\mathbf{C 4}$, and a ratio of 2:1 for complex $\mathbf{C 3}$ at room temperature (Scheme 1). The complexes were obtained as orange, air and moisture stable solids generally soluble in DMSO and DMF but insoluble in ethanol, methanol and water. Complexes $\mathbf{C 1}$ and $\mathbf{C 2}$ are soluble in methylene chloride and chloroform while complexes C3 and C4 are not. The new thiosemocarbazone Pd(II) complexes were characterized by elemental analysis, FTIR, UV-Vis and ${ }^{1} \mathrm{H}$ NMR spectroscopy.

\subsubsection{IR spectroscopic studies}

The infrared spectroscopic data for the imine $v(C=N)$ and thioamide $\nu(C=S)$ vibrations provides very crucial information in determining the coordination mode of the ligand (Table 3). The bands

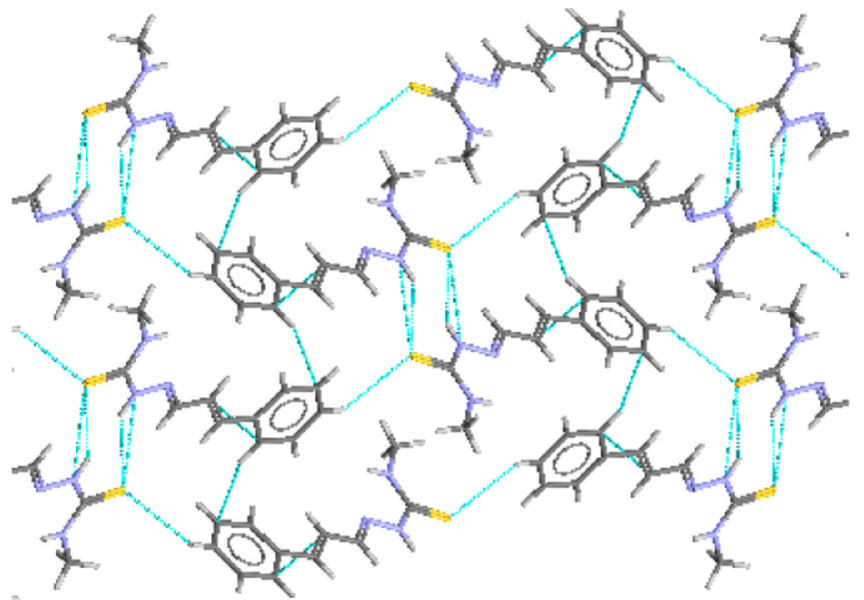

Fig. 5. Crystal packing diagram of L4 as viewed along the crystallographic aaxis. Intermolecular interactions are indicated by dashed lines.

associated with the thioamide vibrations and imine vibrations are generally expected to shift to lower frequencies signaling coordination of the ligand to the metal via the sulphur atom and the imine nitrogen atoms respectively. The shift of spectral bands on chelation of the ligands to the metal through the imine and thioamide linkages reduces the electron density on the pi-bonds, decreases the pi-character and the bond is weakened. In this study, it was observed that the bands in the region $1680-1500 \mathrm{~cm}^{-1}$ associated with imine vibrations are generally split and could be overlapping with the $\nu(\mathrm{N}-\mathrm{H})$ asymmetric stretches, for complexes $\mathbf{C 1}$ and $\mathbf{C 3}$, and, the thiophene/benzene aromatic $v(C=C)$ stretch. These overlaps camouflaged the expected shift to lower energy of the band due to the imine bond $v(\mathrm{C}=\mathrm{N})$ vibration and hence may not be very obvious in the spectra. Despite this observation, the bands associated with imine vibrations are generally shifted to lower frequencies in the spectra of the complexes as compared to the free ligand (Table 3 ). The thioamide $v(\mathrm{C}=\mathrm{S}$ ) bond vibration in complex $\mathrm{C4}$ observed at $1164 \mathrm{~cm}^{-1}$, a lower frequency than that observed for the free ligand, an indication of coordination via the thioamide sulphur atom. The $\nu(C=S)$ vibrations were absent in complexes $\mathbf{C 1}$ and $\mathbf{C 3}$, a sign that the ligands coordinated to the metal in their anionic form through the sulphide, $\mathrm{S}^{-1}$. A very slight shift $\left(7 \mathrm{~cm}^{-1}\right)$ was observed in the $v(C=S)$ vibrations for complex $\mathbf{C 2}$ as compared to ligand $\mathbf{L 2}$, probably due to non-involvement of the $\mathrm{C}=\mathrm{S}$ bond in coordination. The coordination of the TSC ligands through the sulphur and nitrogen atoms was further confirmed by the presence of two new bands at $406-458 \mathrm{~cm}^{-1}$ and $478-508 \mathrm{~cm}^{-1}$ regions due to $v(\mathrm{Pd}-\mathrm{N})$ and $\nu(\mathrm{Pd}-\mathrm{S})$ vibrations respectively. It's worth noting that the $\nu(\mathrm{N}-\mathrm{NH})$ bands in complexes C1 and C3 shifted to higher frequencies. This shift is associated with the electronic delocalization and may have occurred as a consequence of the coordination through the imine nitrogen and deprotonation of TSCs [45]. On the contrary, the $v(\mathrm{~N}-\mathrm{NH})$ vibrations in complexes C2 and C4 did not shift significantly due to none deprotonation of the TSCs and hence absence of resonance. The presence of the a hydrazinic band $\nu(\mathrm{NN}-\mathrm{H})$ in the region $3180-3116 \mathrm{~cm}^{-1}$ for complexes C2 and C4 suggests coordination of the TSC ligands in a neutral manner while its absence in complex $\mathbf{C} \mathbf{1}$ and $\mathbf{C} 3$ suggest deprotonation of the hydrazine nitrogen. The TSC ligands exist in the neutral thione form in the complexes C2 and C4 while in complexes C1 and C3, it probably exists as the anionic thiol form. Despite the expected shift to higher frequency on coordination as a neutral ligand and shift to slightly lower frequency on coordination as a thiolate anion[7], the amine bands $\nu(-\mathrm{N}-\mathrm{H})$ slightly shifted to lower frequency in the complexes compared to the free ligands. The 2-acetyl-5-methyl TSC Pd(II) complexes, $\mathbf{C 1}$ and $\mathbf{C 2}$ exhibited a shift to lower frequency of the bands associated with thiophene $\nu(C-S) 646$ and $536 \mathrm{~cm}^{-1}$ respectively 


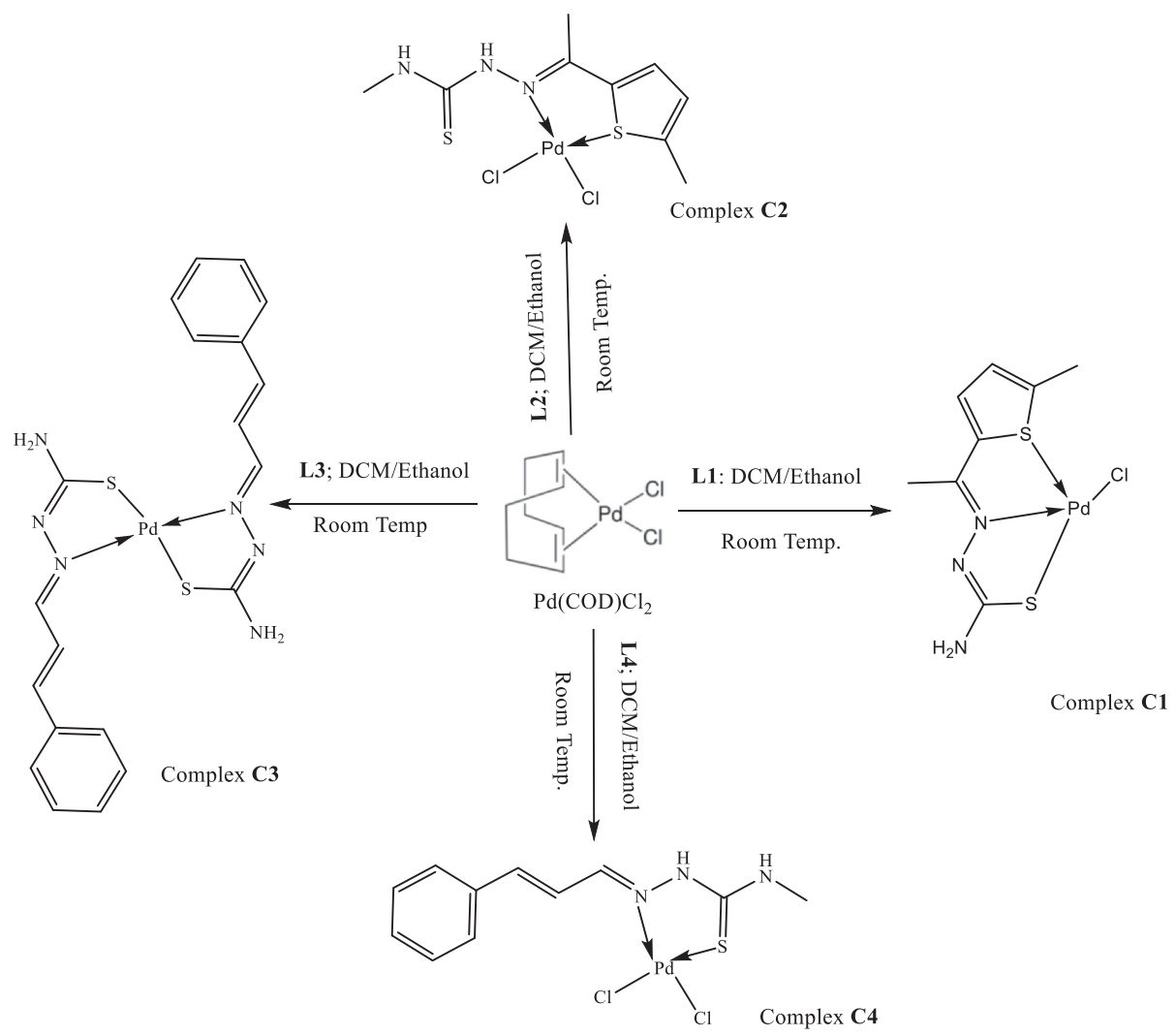

Scheme 1. Synthetic routes for the complexes C1, C2, C3 and C4.

compared to the free ligand bands observed at 796 and $657 \mathrm{~cm}^{-1}$ respectively. This evidence of probable coordination of ligands $\mathbf{L 1}$ and $\mathbf{L 2}$ to the metal via the thiophene sulphur is further supported by the observation of two new Pd-S bands; one for coordination via the thiophene sulphur and the other for coordination via the thioamide sulphur. The spectral studies suggests that the TSC ligand L1 is coordinated to the palladium metal in a tridentate manner forming a complex of general formula $[\mathrm{Pd}(\mathrm{L}) \mathrm{Cl}]$ (Scheme 1) while ligands L2, L3 and $\mathbf{L} 4$ are coordinated in a bidentate manner forming complexes of general formulae $\left[\mathrm{PdL}_{2}\right]$ for complex $\mathbf{C 3}$ and $\left[\mathrm{PdLCl}_{2}\right]$ for complexes $\mathbf{C 2}$ and $\mathbf{C 4}$ (Scheme 1).

\subsection{2. ${ }^{1} H$ NMR analysis}

The ${ }^{1} \mathrm{H}$ NMR data of the complexes and ligands in DMSO- $d_{6}$ are summarized in Table 4. The assignment of the signals in the spectra was based on integrations and assignments previously made for related compounds [7-9]. The ${ }^{1} \mathrm{H}$ NMR data show that the spectra of complexes $\mathrm{C} 2$ and $\mathrm{C} 4$ contain the proton on nitrogen atom of $\mathrm{NN}-\mathrm{H}$ group signal observed in the free ligand, further proof that the ligand is coordinated to the central metal in the neutral thione form. On the other hand, the $\mathrm{NN}-\mathrm{H}$ group proton signal present in NMR spectra of the free ligand is absent the spectra of complexes $\mathbf{C 1}$ and $\mathbf{C 3}$, affirming the proposal made from IR data that the ligands $\mathbf{L} 1$ and $\mathbf{L 3}$ exist in the deprotonated form in the complexes (Figs. S2 and S3). The ${ }^{1} \mathrm{H}$ NMR spectra of complexes showed a downfield shift for the protons of the methyl group attached to the azomethine carbon atom, $\left(\mathrm{CH}_{3}\right) \mathrm{C}=\mathrm{N}$ in complexes $\mathrm{C1}$ and $\mathbf{C 2}$, and the azomethine protons $\mathrm{HC}=\mathrm{N}$ on complexes $\mathbf{C} 3$ and $\mathbf{C 4}$ further confirming coordination of the ligand to the metal centers via the azomethine nitrogen. A downfield shift was also observed for the two thiophene ring protons in the complexes $\mathbf{C 1}$ and $\mathbf{C 2}$, an indication that the ligand may have coordinated to the metal via the thiophene sulphur atom (Table 5).

\subsubsection{UV-Vis electronic spectra analysis}

The electronic spectra of the ligands and complexes in the ultra violet and visible (UV-Vis) region were obtained in dimethyl sulphoxide (DMSO) solvent. The spectra of the ligands exhibited two intraligand bands in the $252-267 \mathrm{~nm}$ and $337-343 \mathrm{~nm}$ regions attributed to $\pi-\pi^{*}$ and $n-\pi^{*}$ transitions, respectively. The intense bands are generally associated with the $\mathrm{C}=\mathrm{S}$ group, $\mathrm{C}=\mathrm{N}$ group and thiophene ring, which are overlapped in ligands L1 and L2 (Fig. S4). Ligands L3 and L4 exhibited intense broad band with shoulders in the region 325-359 nm

Table 3

Selected IR vibration frequencies $\left(\mathrm{cm}^{-1}\right)$ for selected bonds in the ligands and complexes.

\begin{tabular}{|c|c|c|c|c|c|c|c|c|}
\hline Compound & $\nu(-\mathrm{C}=\mathrm{N})$ & $\nu(-\mathrm{C}=\mathrm{S})$ & $\nu(-\mathrm{N}-\mathrm{N})$ & $\nu(-\mathrm{C}-\mathrm{S})$ (Thiophene) & $\nu(\mathrm{Pd}-\mathrm{S})$ & $v(\mathrm{P}--\mathrm{N})$ & $\mathrm{NN}-\mathrm{H}$ & $-\mathrm{N}-\mathrm{H}$ \\
\hline Ligand L1 & 1629,1521 & 1286 & 993 & 796 & - & - & 3119 & 3366,3263 \\
\hline Complex C1 & 1624,1530 & - & 1046 & 646 & 406,478 & 551 & - & 3342,3271 \\
\hline Ligand L2 & 1541,1506 & 1236 & 1042 & 657 & - & - & 3242 & 3331 \\
\hline Complex C2 & 1565,1514 & 1229 & 1048 & 536 & 450,497 & 530 & 3181 & 3272 \\
\hline Ligand L3 & 1588,1521 & 1277 & 1085 & - & - & - & 3147 & 3415,3254 \\
\hline Complex C3 & 1583,1513 & - & 977 & - & 475 & 508 & - & 3420,3259 \\
\hline Ligand L4 & 1532 & 1256 & 1084 & - & - & - & 3164 & 3353 \\
\hline Complex C4 & 1607 & 1164 & 1018 & - & 458 & 501 & 3041 & 3246 \\
\hline
\end{tabular}

The IR spectra of the complexes can be found in the supplementary material file (Fig. S1). 
Table 4

${ }^{1} \mathrm{H}$ NMR data (ppm) for the ligands and complexes.

\begin{tabular}{|c|c|c|c|c|c|c|c|}
\hline Compound & $\delta(\mathrm{NNH})$ & $\delta\left(\mathrm{NH}_{2}\right) /(\mathrm{NH})$ & $\delta(\mathrm{HC}=\mathrm{N})$ & $\delta\left(\mathrm{C}_{4} \mathrm{H}_{2} \mathrm{~S}\right)$ (thiophene) & $\delta\left(\mathrm{CH}_{3}\right)$ (thiophene) & $\delta\left(\mathrm{CH}_{3}\right)-\mathrm{C}=\mathrm{N}$ & $\delta\left(\mathrm{CH}_{3}\right) \mathrm{N}\left(\mathrm{CH}_{3}\right)$ \\
\hline L1 & 10.32 & 7.34 & - & $7.31,6.78$ & 2.28 & 2.42 & - \\
\hline C1 & - & 8.25 & - & $7.45,6.85$ & 2.36 & 2.45 & - \\
\hline L2 & 10.25 & 7.98 & - & $7.30,6.72$ & 2.26 & 2.43 & 3.02 \\
\hline $\mathrm{C} 2$ & - & - & - & $7.49,6.87$ & 2.47 & 2.58 & 2.90 \\
\hline L3 & 11.4 & $8.19,7.62$ & 7.9 & - & - & - & - \\
\hline C3 & - & 7.62 & 8.08 & - & - & - & - \\
\hline L4 & 11.46 & 8.30 & 7.91 & & & & 2.94 \\
\hline C4 & 11.10 & 7.62 & 8.08 & - & - & - & 2.83 \\
\hline
\end{tabular}

Table 5

Electronic data for the ligands and Pd(II) complexes.

\begin{tabular}{|c|c|c|c|c|c|}
\hline \multirow{2}{*}{$\begin{array}{l}\text { Compounds } \\
\text { "L1 }\end{array}$} & \multicolumn{5}{|c|}{$\lambda_{\max }, \mathrm{nm}\left(\varepsilon, \mathrm{M}^{-1} \mathrm{~cm}^{-1}\right)$} \\
\hline & & & 341 (1030) & & \\
\hline C1 & & 291 (1589) & 342 (1166) & 393 (433) & 480 (218) \\
\hline L2 & & & $342(1000)$ & & \\
\hline $\mathrm{C} 2$ & & & 340 (1472) & 393 (417) & 486 82.7) \\
\hline **L3 & & & & 345 (1470) & $\begin{array}{l}358 \mathrm{sh} \\
(11248)\end{array}$ \\
\hline${ }^{*} \mathrm{C} 3$ & & 303 (1770) & 362 (1920) & 417 (1430) & 486 (97) \\
\hline L4 & & & & 344 (1487) & 361 (1163) \\
\hline C4 & 297 (1271) & & 370 (1690) & 388 (1681) & $470(46.2)$ \\
\hline
\end{tabular}

Note: $10^{-3} \mathrm{M}$ solution of each compound in DMSO was scanned at $200-800 \mathrm{~nm}$ range; * $5 \times 10^{-4} \mathrm{M}$ solution used; **1.5 $\times 10^{-3} \mathrm{M}$.

associated with the overlap of the $-\mathrm{C}=\mathrm{C}$ - group of the benzene ring.

These bands associated with the $\mathrm{C}=\mathrm{S}$ and $\mathrm{C}=\mathrm{N}$ groups exhibited a red shift of between 20 and $61 \mathrm{~nm}$ after coordination of the ligands $\mathbf{L 2}$ and $\mathbf{L} 4$ to the metal center through the imine nitrogen and thiol sulphur respectively. This observation is in agreement with others earlier reported for palladium TSC complexes $[9,46]$. The spectra of complexes exhibited new strong bands resulting from ligand to metal charge transfer (LMCT) in the region $338-478 \mathrm{~nm}$. These bands may be assigned to S-Pd charge transfer further supporting coordination of the ligand to the metal via the sulphur atom of the $\mathrm{C}=\mathrm{S}$ group in the neutral thiol form in C2 and C4 and anionic form in C1 and C3. The spectra of complexes $\mathbf{C 1}$ and $\mathbf{C 2}$ each had a new band at $483 \mathrm{~nm}$, a further indication that the thiophene sulphur is also involved in coordination as suggested by the FT-IR data. On the contrary, the UV-Vis spectra of complexes C3 and C4, which do not bear the thiophene group, did not show any bands at $483 \mathrm{~nm}$. The Pd(II) ion has $\mathrm{d}^{8}$ configuration and is expected to show three bands in the electronic spectrum since palladium complexes have a square planar geometry corresponding to the ${ }^{1} \mathrm{~A}_{1 \mathrm{~g}} \rightarrow{ }^{1} \mathrm{~A}_{2 g},{ }^{1} \mathrm{~A}_{1 g} \rightarrow{ }^{1} \mathrm{~B}_{1 g}$, and ${ }^{1} \mathrm{~A}_{1 g} \rightarrow{ }^{1} \mathrm{E}_{g}$ transitions [8]. The presence of the $S$ and $N$ atoms makes the spectra of Pd(II) complexes complicated since the tails of the S-Pd band may extend up to the visible region of the spectrum thus obscuring the expected $d-d$ transitions. The elemental analysis data obtained for the complexes and the ligands further confirmed the composition and reaction ratio of the ligands and metal ions and hence the proposed molecular structures and coordination modes.

The conductivity measurements of solutions the metal complexes in DMSO indicated that the Pd(II) complexes are non-electrolytes since the values obtained for the compounds were the same as that observed for pure DMSO (Table 6). This clearly shows that the chloride in complexes

Table 6

Conductivity values for the Pd(II) complexes in DMSO.

\begin{tabular}{llllll}
\hline Metal complexes & {$[\mathrm{Pd}(\mathbf{L} 1) \mathrm{Cl}]$} & {$\left[\mathrm{Pd}(\mathbf{L} 2) \mathrm{Cl}_{2}\right]$} & {$\left[\mathrm{Pd}(\mathbf{L} 3)_{2}\right]$} & {$\left[\mathrm{Pd}(\mathbf{L} 4) \mathrm{Cl}_{2}\right]$} & $\mathrm{DMSO}$ \\
\hline $\begin{array}{c}\text { Conductivity mS/ } \\
\text { cm }\end{array}$ & 0.24 & 0.23 & 0.24 & 0.23 & 0.25 \\
& & & & & \\
\hline
\end{tabular}

C1, C2 and C4 are within the coordination sphere. This is an indication that the complexes are neutral non-electrolytes with coordinated chloride.

The spectroscopic analyses, elemental analysis data and conductivity measurements suggest that the palladium complexes the complexes exhibit coordination modes and structures illustrated in Scheme 1.

It is worth noting that attempts to grow crystals for single crystal Xray crystallography was not successful.

\subsection{Biological studies}

\subsubsection{Cytotoxicity studies}

The cytotoxicity of the ligands and their corresponding $\mathrm{Pd}(\mathrm{II})$ complexes were screened against the human cancer (Caco-2, HeLa, HepG2, MCF-7, PC-3) and non-cancer (MCF-12A) cells. The cells were exposed to $100 \mu \mathrm{M}$ of each compound for $24 \mathrm{~h}$, the cell viability in response to treatments was assessed following MTT assay and expressed as \% cell viability. As shown in Fig. 6 , the ligands demonstrated varying degrees of toxicity against the test cells. $\mathbf{L} \mathbf{1}$ and $\mathbf{L} \mathbf{3}$ were the most active and exhibited $<40 \%$ cell viability in two or three cell lines i.e. PC-3, HepG2 and Caco- 2 cells. The PC-3 and HepG2 cells showed higher susceptibility to three (L1, L3 and L4) and four ligands, respectively.

The cytotoxic effect of the ligands on the cells was enhanced after coordination to the Pd metal, thus the cytotoxic effects of the Pd(II) complexes were significantly higher than the ligands. Treatment with $100 \mu \mathrm{M}$ of the Pd(II) complexes resulted in non-selective reduction in proliferation of both cancer and non-cancer cells. In essence, the complexes were more lethal to the cancer cells compared to their respective ligands. A few exceptions where the ligands were more potent than the Pd(II) complexes were observed, for instance, C3 versus L3 against Caco-2 (29.4\% vs $35.5 \%)$ and C1 versus L1 against PC-3 (7.7\% vs 10\%) cells.

The concentration of the compounds that inhibited 50\% cell proliferation $\left(\mathrm{IC}_{50}\right)$ on each cell line was estimated using GraphPad Prism software version 5 (Table 7). The $\mathrm{IC}_{50}$ values revealed that for the ligands to inhibit $50 \%$ cell proliferation, $\mathrm{IC}_{50}$ values of more $100 \mu \mathrm{M}$ was required, with the exception of $\mathbf{L 1}$ and L2 on HepG2 and MCF-7 cells. L1 had an IC $\mathrm{I}_{50}$ value of $45.3 \mu \mathrm{M}$ against the human breast cancer cells (MCF-7) and $85 \mu \mathrm{M}$ on HepG2; and $54 \mu \mathrm{M}$ for L2 on HepG2 cells. The Pd(II) complexes were observed to be more active in preventing cell proliferation than the free ligands. Some of the Pd(II) complexes were more potent against specific cell lines with C2, C3 and C4 exhibiting a broad spectrum potency against all the human cancer cell lines tested. The activity of $\mathbf{C} \mathbf{2}$ against the proliferation of the cells tested increased in the order Caco- $2<$ HepG2 < MCF-7 < HeLa < PC3. All the Pd (II) complexes (C1, C2, C3 and C4) exhibited very good activity against the human prostate cancer cell (PC-3) in the order $\mathbf{C 3}>\mathbf{C 2}>\mathbf{C 1}>$ C4, with the $\mathrm{IC}_{50}$ values ranging between $2.0 \mu \mathrm{M}$ (C3) and $9.6 \mu \mathrm{M}$ (C4). The $\mathrm{IC}_{50}$ values previously reported for the Pd(II) thiosemicazone complexes against PC-3 cells were much higher $(48-58 \mu \mathrm{M})$ [4] when compared to the ones reported herein $(2.0-9.0 \mu \mathrm{M})$. C2 was an excellent candidate for breast cancer (MCF-7) cells because the 

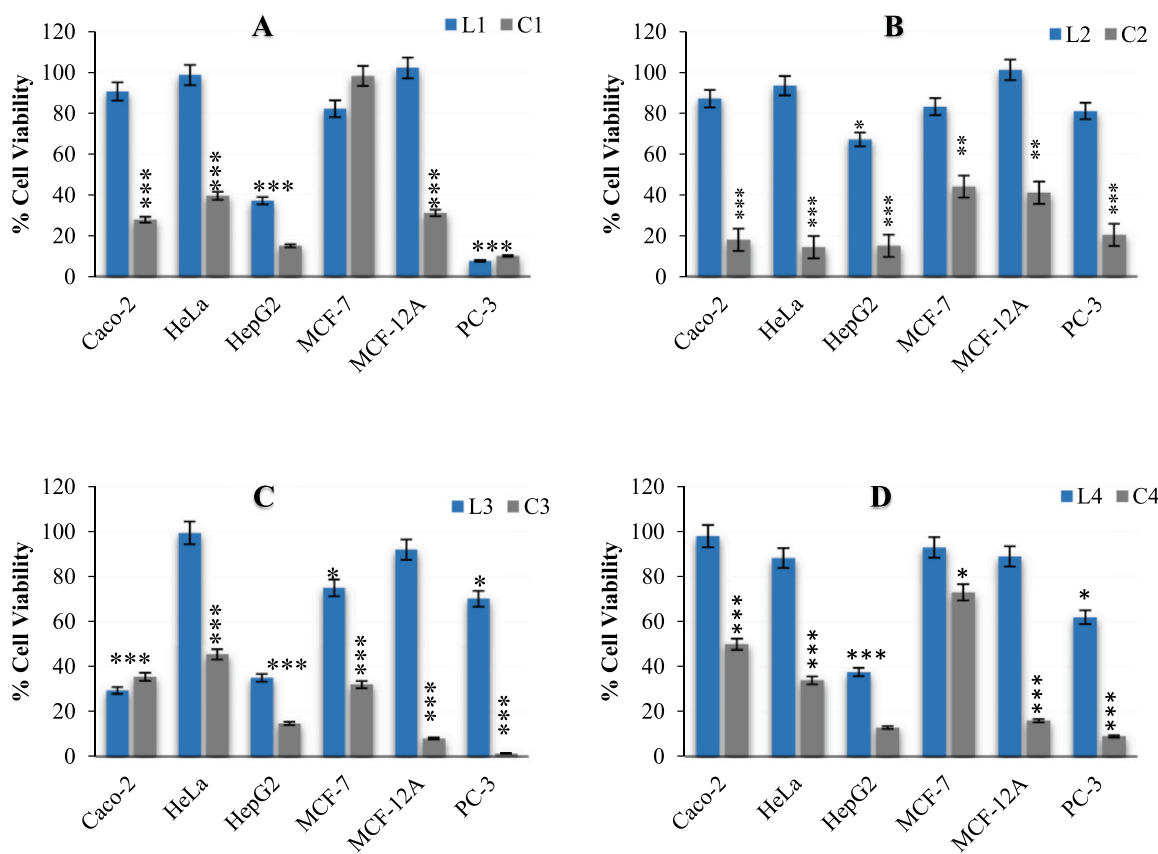

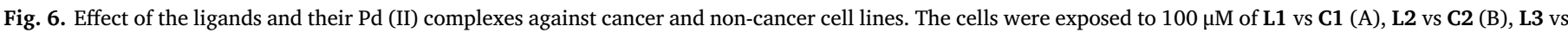
C3 (C), and L4 vs C4 (D). *p $\leq 0.05,{ }^{* *} \mathrm{p} \leq 0.01,{ }^{* * *} \mathrm{p} \leq 0.001$.

concentration needed to inhibit $50 \%$ cell proliferation was $7.6 \mu \mathrm{M}$ compared to the $\mathrm{IC}_{50}$ for the non-cancer breast (MCF-12A) cells. The $\mathrm{IC}_{50}$ value for C2 against the MCF-7 cells is comparable to the $\mathrm{IC}_{50}$ values $(4.41 \mu \mathrm{M}$ and $48.0 \mu \mathrm{M})$ reported for Pd complexes on the same cell line [10]. Of all the compounds tested, C2 was the most potent against the cancer cells. The $\mathrm{IC}_{50}$ values observed in this study are comparable to those reported for Pd(II) complexed with indole-3-carbaldehyde thiosemicarzone in literature [47]. It is worth noting, from the data obtained, that the presence or absence of coordinated chloride ion may or may not influence the inhibition of cancer cell proliferation. For instance, $\mathbf{C 2}$ and $\mathbf{C 4}$ each had two coordinated chloride ions but C2 exhibited higher cytotoxicity mostly on cancer cells while $\mathbf{C} 4$ was toxic to all cells (Table 7). The difference in activity between the two complexes can probably be associated with the presence of the two sulphur atoms in C2 and only one sulphur atom in C4.

\section{Conclusion}

The crystal structures confirm the formation of $\mathbf{L} 2$ and $\mathbf{L} 4$. The new Pd(II) complexes of 2-acetyl-5-methyl thiophene and CIN thiosemicarbazones were successfully synthesized and their in vitro anticancer activities against five human cancer cell lines (colon, cervix, hepatocellular, breast and prostate) and non-cancer breast cells were determined. The thiosemicarbazone L2, L3 and L4 coordinated to the metal via the nitrogen and sulphur (N,S fashion) of the of the thiosemicarbazide fragment in a bidentate manner while $\mathbf{L} 1$ coordinated to the metal in a tridentate manner via the nitrogen and Sulphur of the thiosemicarbazide fragment, and Sulphur of the thiophene fragment (S,N,S fashion). Conductivity measurements done on the complexes showed that the complexes are non-electrolytes an indication that the chloride ions are within the coordination sphere. This also confirms that the thiosemicarbazones in complexes C1, C2 and C4 are coordinated anions of the thiol tautomer. Except for $\mathbf{L} 1$ which gave an $\mathrm{IC}_{50}$ value of 45.3 $\mu \mathrm{M}$ against HepG2 cancer cells, the ligands generally did not show growth inhibition against any of the cells tested at IC $_{50}$ values below $50 \mu \mathrm{M}$. The Pd(II) complexes exhibited excellent growth inhibition against all the human cancer cells tested, which was reduced in the noncancer breast cells. C3 had an $\mathrm{IC}_{50}$ value of $2.0 \mu \mathrm{M}$ against the PC-3 cancer cells and can be a suitable candidate for prostate cancer. Further studies are underway to investigate the selectivity of the complexes and their mechanism of action.

Table 7

$\mathrm{IC}_{50}$ of ligands and Pd complexes.

\begin{tabular}{|c|c|c|c|c|c|c|}
\hline \multirow[t]{2}{*}{ Samples } & \multicolumn{6}{|l|}{$\mathrm{IC}_{50}(\mu \mathrm{M})$} \\
\hline & Caco-2 & MCF-12A & HeLa & PC-3 & HepG2 & MCF-7 \\
\hline L1 & $>100$ & $>100$ & $>100$ & $>100$ & $84.85 \pm 2.01$ & $45.25 \pm 2.57$ \\
\hline $\mathrm{C} 1$ & $74.14 \pm 3.16$ & $>100$ & $>100$ & $5.53 \pm 0.49$ & $16.26 \pm 1.08$ & $72.65 \pm 1.96$ \\
\hline L2 & $>100$ & $>100$ & $>100$ & $>100$ & $54.03 \pm 3.54$ & $>100$ \\
\hline $\mathrm{C} 2$ & $15.92 \pm 2.01$ & $>100$ & $7.92 \pm 0.07$ & $5.3 \pm 0.03$ & $11.68 \pm 2.79$ & $9.53 \pm 2.90$ \\
\hline L3 & $>100$ & $>100$ & $>100$ & $>100$ & $>100$ & $>100$ \\
\hline $\mathrm{C} 3$ & $27.87 \pm 0.50$ & $5.15 \pm 0.52$ & $>100$ & $1.99 \pm 0.21$ & $>100$ & $10.06 \pm 3.31$ \\
\hline $\mathrm{L} 4$ & $>100$ & $90.6 \pm 5.52$ & $>100$ & $>100$ & $>100$ & $>100$ \\
\hline $\mathrm{C} 4$ & $76.24 \pm 3.15$ & $21.92 \pm 0.05$ & $52.44 \pm 0.63$ & $9.6 \pm 2.32$ & $9.61 \pm 0.58$ & $48.76 \pm 4.55$ \\
\hline
\end{tabular}

${ }^{\mathrm{a}}$ Data represents the mean values of three independent experiments. 


\section{Declaration of Competing Interest}

The authors declare that they have no known competing financial interests or personal relationships that could have appeared to influence the work reported in this paper.

\section{Acknowledgements}

We would like to thank Jomo Kenyatta University of Agriculture and Technology in Kenya for granting Dr. Eunice Nyawade study leave to undertake this study at the University of the Western Cape, South Africa. We would also like to thank the following research groups: "Organometallics and Nanomaterials" and "DSI/Mintek NIC Biolabels Node" at UWC for allowing us to use their facilities.

\section{Funding}

This work was supported by the National Research Foundation, South Africa [grant numbers UD: 116692.

\section{Appendix A. Supplementary data}

CCDC2009031 and 2009034 contain the supplementary crystallographic data for this paper. These data can be obtained free of charge via http://www.ccdc.cam.ac.uk/conts/retrieving.html (or from the Cambridge Crystallographic Data Centre, 12, Union Road, Cambridge CB2 1EZ, UK; fax: + 441223 336033). Supplementary data to this article can be found online at https://doi.org/10.1016/j.ica.2020. 120036.

\section{References}

[1] D. Kovala-Demertzi, A. Boccarelli, M.A. Demertzis, M. Coluccia, Chemotherapy 53 (2007) 148-152.

[2] X.-Y. Qin, Y.-N. Wang, X.-P. Yang, J.-J. Liang, J.-L. Liu, Z.-H. Luo, Dalton Trans. 46 2017) 16446-16454.

[3] E. Ramachandran, V. Gandin, R. Bertani, P. Sgarbossa, K. Natarajan, N.S.P. Bhuvanesh, A. Venzo, A. Zoleo, M. Mozzon, A. Dolmella, A. Albinati, C. Castellano, N. Reis Conceição, M.F.C. Guedes da Silva, C. Marzano, Molecules 1868 (2020) 25.

[4] S.N. Mbugua, N.R.S. Sibuyi, L.W. Njenga, R.A. Odhiambo, S.O. Wandiga, M. Meyer, R.A. Lalancette, M.O. Onani, ACS Omega 5 (2020) 14942-14954.

[5] R.M. El-Shazly, G.A.A. Al-Hazmi, S.E. Ghazy, M.S. El-Shahawi, A.A. El-Asmy, J. Coord. Chem. 59 (2006) 845-859.

[6] P. Indrani, B. Falguni, B. Samaresh, Angew. Chem. Int. Ed. 40 (2001) 2923-2925.

[7] T.S. Lobana, R. Sharma, G. Bawa, S. Khanna, Coord. Chem. Rev. 253 (2009) 977-1055.

[8] A.A. Ali, H. Nimir, C. Aktas, V. Huch, U. Rauch, K.-H. Schäfer, M. Veith, Organometallics 31 (2012) 2256-2262.

[9] A. Karaküçüik-İyidoğan, D. Tașdemir, E.E. Oruç-Emre, J. Balzarini, Eur. J. Med. Chem. 46 (2011) 5616-5624.

[10] A.I. Matesanz, I. Leitao, P. Souza, J. Inorg. Biochem. 125 (2013) 26-31.

[11] P. Kalaivani, C. Umadevi, R. Prabhakaran, F. Dallemer, P.S. Mohan, K. Natarajan, Polyhedron 80 (2014) 97-105.

[12] N. Bharti, K. Husain, M.T. Gonzalez Garza, D.E. Cruz-Vega, J. Castro-Garza, B.D. Mata-Cardenas, F. Naqvi, A. Azam, Bioorg. Med. Chem. Lett. 12 (2002)
3475-3478.

[13] L. Feun, M. Modiano, K. Lee, J. Mao, A. Marini, N. Savaraj, P. Plezia, B. Almassian, E. Colacino, J. Fischer, S. MacDonald, Cancer Chemother. Pharmacol. 50 (2002) 223-229.

[14] A.G. Quiroga, J.M. Pérez, I. López-Solera, J.R. Masaguer, A. Luque, P. Román, A. Edwards, C. Alonso, C. Navarro-Ranninger, J. Med. Chem. 41 (1998) 1399-1408.

[15] C. Shipman, S.H. Smith, J.C. Drach, D.L. Klayman, Antiviral Res. 6 (1986) 197-222.

[16] D.C. Quenelle, K.A. Keith, E.R. Kern, Antiviral Res. 71 (2006) 24-30.

[17] R.F.F. Costa, A.P. Rebolledo, T. Matencio, H.D.R. Calado, J.D. Ardisson, M.E. Cortés, B.L. Rodrigues, H. Beraldo, J. Coord. Chem. 58 (2005) 1307-1319.

[18] R.K. Agarwal, L. Singh, D.K. Sharma, Bioinorg. Chem. Appl. 2006 (2006) 10.

[19] M. Vieites, L. Otero, D. Santos, J. Toloza, R. Figueroa, E. Norambuena, C. Olea-Azar, G. Aguirre, H. Cerecetto, M. González, A. Morello, J.D. Maya, B. Garat, D. Gambino, J. Inorg. Biochem. 102 (2008) 1033-1043.

[20] M. Vieites, L. Otero, D. Santos, C. Olea-Azar, E. Norambuena, G. Aguirre, H. Cerecetto, M. González, U. Kemmerling, A. Morello, J. Diego Maya, D. Gambino, J. Inorg. Biochem. 103 (2009) 411-418.

[21] R.B. de Oliveira, E.M. de Souza-Fagundes, R.P.P. Soares, A.A. Andrade, A.U. Krettli, C.L. Zani, Eur. J. Med. Chem. 43 (2008) 1983-1988.

[22] P. Yogeeswari, D. Sriram, L.R.J. Sunil Jit, S.S. Kumar, J.P. Stables, Eur. J. Med. Chem. 37 (2002) 231-236.

[23] T. Nitoda, M.D. Fan, I. Kubo, Phytother. Res. 22 (2008) 809-813.

[24] L. Liang-Tzung, T. Chen-Jei, C. Shun-Pang, C. Jin-Liang, W. Shu-Jing, L. ChunChing, Anti-Cancer Agents Med. Chem. 13 (2013) 1565-1574.

[25] H. Su-Hyung, I.I. Ahmed, K. Sung-Min, H.D. Cho, K. Byoung-Mog, Phytother. Res. 30 (2016) 754-767.

[26] D.T. Shaughnessy, R.W. Setzer, D.M. DeMarini, Mutat. Res./Fundam. Mol. Mech. Mutag. 480-481 (2001) 55-69.

[27] T. Ohta, K. Watanabe, M. Moriya, Y. Shirasu, T. Kada, Mutat. Res./Fundam. Mol. Mech. Mutag. 107 (1983) 219-227.

[28] C. Bang-Jiao, F. Chun-Sheng, L. Guo-Hui, W. Xiao-Ning, L. Hong-Xiang, R. DongMei, S. Tao, Mini-Rev. Med. Chem. 17 (2017) 33-43.

[29] F. Bisceglie, S. Pinelli, R. Alinovi, M. Goldoni, A. Mutti, A. Camerini, L. Piola, P. Tarasconi, G. Pelosi, J. Inorg. Biochem. 140 (2014) 111-125.

[30] E.A. Nyawade, H.B. Friedrich, B. Omondi, H.Y. Chenia, M. Singh, S. Gorle, J, Organomet. Chem. 799-800 (2015) 138-146.

[31] F.R. Pavan, G.V. Poelhsitz, M.I.F. Barbosa, S.R.A. Leite, A.A. Batista, J. Ellena, L.S. Sato, S.G. Franzblau, V. Moreno, D. Gambino, C.Q.F. Leite, Eur. J. Med. Chem. 46 (2011) 5099-5107.

[32] J. Wiedermann, K. Mereiter, K. Kirchner, J. Mol. Catal. A: Chem. 257 (2006) 67-72.

[33] E.-J. Gao, F. Hong, M.-C. Zhu, C. Ma, S.-K. Liang, J. Zhang, L.-F. Li, L. Wang, Y.Y. Li, J. Wei, Eur. J. Med. Chem. 82 (2014) 172-180.

[34] Bruker-AXS, Bruker-AXS, Madison, Wisconsin, USA, 2009

[35] G.M. Sheldrick, Acta Crystallogr. A A64 (2008) 112-122.

[36] A.L. Spek, Acta Crystallogr. D D65 (2009) 148-155.

[37] K. Brandenburg and H. Putz, Crystal Impact GbR, Bonn, Germany, 2005.

[38] M.A. Ali, S.M.M.-u.-H. Majumder, R.J. Butcher, J.P. Jasinski, J.M. Jasinski, Polyhedron 16 (1997) 2749-2754.

[39] N. Bharti, Shailendra, S. Sharma, F. Naqvi, A. Azam, Bioorg. Med. Chem. 11 (2003) 2923-2929.

[40] I. Antonini, F. Claudi, P. Franchetti, M. Grifantini, S. Martelli, J. Med. Chem. 20 (1977) 447-449.

[41] P.K. Yaman, B. Şen, C.S. Karagöz, E. Subaşı, J. Organomet. Chem. 832 (2017) 27-35.

[42] Z.-L. Jing, M. Yu, X. Chen, Acta Crystallogr. Section E 63 (2007) 03714.

[43] P.A. Gaye, A. Sy, A.D. Sarr, M. Gaye, C. Besnard, Acta Crystallogr. Section E 67 (2011) 01168.

[44] P. Murali Krishna, G.N. Anilkumar, K. Hussain Reddy, M.K. Kokila, Acta Crystallogr. Section E 68 (2012) o2842.

[45] D. Gambino, L. Otero, M. Vieites, M. Boiani, M. González, E.J. Baran, H. Cerecetto, Spectrochim. Acta Part A Mol. Biomol. Spectrosc. 68 (2007) 341-348.

[46] L. Papathanasis, M.A. Demertzis, P.N. Yadav, D. Kovala-Demertzi, C. Prentjas, A. Castiñeiras, S. Skoulika, D.X. West, Inorg. Chim. Acta 357 (2004) 4113-4120.

[47] J. Haribabu, M.M. Tamizh, C. Balachandran, Y. Arun, N.S.P. Bhuvanesh, A. Endo, R. Karvembu, New J. Chem. 42 (2018) 10818-10832. 